\title{
Rate of Reduction of Liquid Iron Oxide
}

Tetsuya NAGASAKA and Shiro BAN-YA

\section{1. 緒言}

溶融酸化鉄の還元速度は, 最近国家プロジェクト規模 で活発な開発研究が進められている溶融還元製鉄法 ${ }^{1)}$ 理解する上で重要な基礎的知見である. 一方, 現行の高 炉製鉄法においては，最近高炉機能の拡大が指向される 中で, 低コークス比, 低 $\mathrm{Si}$ 操業を目的とした羽口から の微粉炭, 粉鉱石吹き込み ${ }^{2)}$ が積極的に行なわれており, この際にも溶融酸化鉄の還元機構の解明が必須の課題で あるとされている. しかしながら，溶融酸化鉄の還元速 度に関する基礎研究は, 実験的困難性及びその現象の複 雑さのため極めて㙰弱な状況にあり, 現状ではいまだ反 応機構に関する定量的説明は困難である.

溶融酸化鉄の還元速度に関する実験室規模の基礎研究 は 1951 年頃から行なわれ, その後特に我が国と旧ソ連 を中心に, 今日に至るまで約 45 件程度の研究例が報告 されている.これら過去になされた基礎研究例の紹介に ついては, 森 ${ }^{3)}$, 中村ら ${ }^{4)}$, 相馬 ${ }^{5)}$, 徳田6), 及び不破 ${ }^{7)}$ による優れた邦文の解説がある.

酸化鉄の溶融還元は, 少なくとも三つ以上の相よりな る典型的な高温不均一反応系である. すなわち, 高温で 酸化鉄融体と炭材を接触させれば, 酸化鉄は還元されて 金属鉄相を生成する.この際, 反応は激しいガス発生を 伴い, スラグの泡立ちによる反応界面積の変化や生成ガ スによる副次的反応等が生じ, 現象は非常に複雑である. 従って, 還元の律速段階や反応機構を実験的に解明する 事は容易ではない. 特に, 泡立った酸化物融体中におけ る物質移動現象を定量的に論じる事は現状では極めて困 難である. 従って, 従来の研究でも反応機構に関しては, 一部を除けば定性的な説明しかなされていない.

しかし, 反応機構を解明する事は別にしても, 既報の 溶融還元速度の実測値を相互に比較検討し, 何がどこま で明らかになっているかを明確にしておくことは, 溶融 還元プロセスの工業化が現実味を帯びつつある現時点で は意味のある事と考えられる，そこで本稿では，溶融酸
化鉄の還元速度に関する実験室規模の基礎研究にのみ内 容を絞り，諸家により実測された総括還元速度のデー夕 をできる限り忠実に分類・比較し, 可能な限り眓示した.

\section{2. 溶融酸化鉄の還元方式}

溶融酸化鉄の還元方式は，還元剤の種類により次の三 つに大別され，各総括還元反応は(1) ( 4 )式で示され る.

[ 1 ]固体炭素による還元（固液系）

$$
\mathrm{Fe}_{t} \mathrm{O}(\mathrm{l})+\mathrm{C}(\mathrm{s})=t \mathrm{Fe}(\mathrm{l} \text { or } \mathrm{s})+\mathrm{CO}(\mathrm{g})
$$

[2]溶融 $\mathrm{Fe}-\mathrm{C}$ 合金による還元 (液液系)

$\mathrm{Fe}_{t} \mathrm{O}(\mathrm{l})+\underline{\mathrm{C}}=t \mathrm{Fe}(\mathrm{l}$ or $\mathrm{s})+\mathrm{CO}(\mathrm{g}) \cdots \cdots(2)$

[ 3 ]ガスによる還元 (気液系)

$\mathrm{Fe}_{t} \mathrm{O}(\mathrm{l})+\mathrm{H}_{2}(\mathrm{~g})=t \mathrm{Fe}(\mathrm{l}$ or s $)+\mathrm{H}_{2} \mathrm{O}(\mathrm{g})$

$\mathrm{Fe}_{t} \mathrm{O}(\mathrm{l})+\mathrm{CO}(\mathrm{g})=t \mathrm{Fe}(\mathrm{l}$ or $\mathrm{s})+\mathrm{CO}_{2}(\mathrm{~g})$

なお, 研究者によっては酸化鉄試料として $\mathrm{Fe}_{2} \mathrm{O}_{3}$ や $\mathrm{Fe}_{3} \mathrm{O}_{4}$ を用いている場合もある. $\mathrm{Fe}_{2} \mathrm{O}_{3}$ や $\mathrm{Fe}_{3} \mathrm{O}_{4}$ を初 期試料として用いても, 溶融還元が進行し, 金属鉄を生 成する段階では酸化鉄は $\mathrm{Fe}_{t} \mathrm{O}$ とみなせるものと考えら れる.

[ 1 ] は最も基本的な還元剂である固体炭素を用いた研 究で, 過去の研究の約半数がこの範疇に属する. [2]は 最近開発が進められつつある鉄浴式溶融還元法 ${ }^{11} に$ 対忍 した方式であり，実用上最も重要性が高い系であると考 えられる. [3]は, [1]，［2]のいずれの系においても 反応に伴って必ず CO ガスが発生する宿命上, 溶融還 元反応を理解する上で重要な位置を占めていると考えら れる：本系では反応界面積が実験的に規定でき，[1]， [2]の系に比べてはるかに精度の高い測定が可能であ る.

(1) （4)式中で, $\mathrm{Fe}_{t} \mathrm{O}$ が純物質か溶融スラグ中に 溶解しているかによって反応形態は更に分類される. 


\section{3. 還元速度の定義}

本稿では，諸家による溶融還元速度の測定結果を( 5 ) 式で定義される単位時間，単位界面積当たりの酸素の除 去速度 $r$ として再評価し, 相互に比較検討した。

$r=\left(d W_{\mathrm{O}} / d t\right) / A\left(\mathrm{~kg}-\right.$ oxygen $\left./ \mathrm{m}^{2} \mathrm{~s}\right) \cdots \cdots \cdots \cdots(5)$

ここで， $W_{\mathrm{O}}$ は還元除去された酸素重量 $(\mathrm{kg}), t$ は反 応時間 $(\mathrm{s}), A$ は反応界面積 $\left(\mathrm{m}^{2}\right)$ である. $r$ を計算 するにあたっては, 各文献中で還元速度の代表值として 評価されている值をできる限り忠実に採用した。また， $r$ を計算する際には反応界面積 $A$ の評価が重要である. 各文献中で反応界面積が記載されている場合は必ずしも 多くないが, 不明の場合は実験装置の幾何形状から推定 した。ただし後述するように，固液，液液系では真の反 応界面積の評価は現状では極めて困難であり，これが還 元速度の評価に大きな誤差を与えている.

\section{4. 純粋な酸化鉄の溶融還元速度}

溶融還元法を考える上で，溶融純酸化鉄の還元速度は その基準となる重要な值である．溶融純酸化鉄を還元し た場合，その過程で酸化鉄の活量は常に一定で $a_{\mathrm{Fe}_{t} \mathrm{O}}=$ 1 であり，還元によって酸化鉄の量が減少するだけであ る. 従って，温度が一定に保たれれば，生成した金属鉄 相により反応が物理的に阻害されない限り還元速度は一 定の值を示すと考えられ，反応機構の検討にあたっては 好都合である.しかし，溶融純酸化鉄の還元速度の研究 報告は 17 件しか見当たらず，必ずしも十分検討されて いるとはいえない状態である.

\section{$4 \cdot 1$ 固体炭素による還元 (固液系)}

本系に関する研究はこれまで 7 件 $^{8) ~ 14)}$ の報告があり, いずれも我が国と旧ソ連における研究である。これらの 研究における実験条件を Table 1 にまとめて示す.

諸家によって測定された純溶融酸化鉄の固体炭素によ る還元速度と温度の関係を Fig. 1 に比較して示す.な お加藤ら ${ }^{10)}$ は, $\mathrm{Fe}_{t} \mathrm{O}$ と黒鉛の混合粉末を圧縮成型して 還元実験に供しており，このような方法では反応界面積
の評価が困難であるため, 比較対象から除外した。

本系における還元速度は, Ryzenkov ら ${ }^{8)}$, Kondakov ら 9)が 1960 年に初めて測定した. 彼らは, 減压下で黒 鉛るつぼに少量の $\mathrm{Fe}_{t} \mathrm{O}$ を落下させて還元実験を行な い，還元率が約 $50 \%$ の時に得られる還元速度の最大值 を代表值としている．還元速度は全压に比例することか ら,ガス相が還元反応に寄与する可能性を指摘している.

その後, 本系における溶融還元速度は我が国において

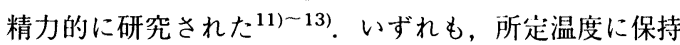
した黒鉛るつぼ中に酸化鉄を投入し，発生ガス量より還 元速度を求めている. 試料は投入後約 $30 \mathrm{~s}$ 以内に完全 に溶融し，激しいガス発生を伴いながら還元が進行し， 還元率が $100 \%$ に近づくにつれて反応は鎮静化する. 反 応界面積は，溶融酸化鉄の泡立ち高さを測定して求めた 融体と黒鉛の接触面積と等しいとおいている，還元速度 の代表值は，試料が完全に溶融し，還元率が約 $50 \%$ の 時に得られる一定の速度を取っている．また佐藤ら は, 鉄または $\mathrm{Al}_{2} \mathrm{O}_{3}$ るつぼで溶融させた $\mathrm{Fe}_{t} \mathrm{O}$ に黒鉛

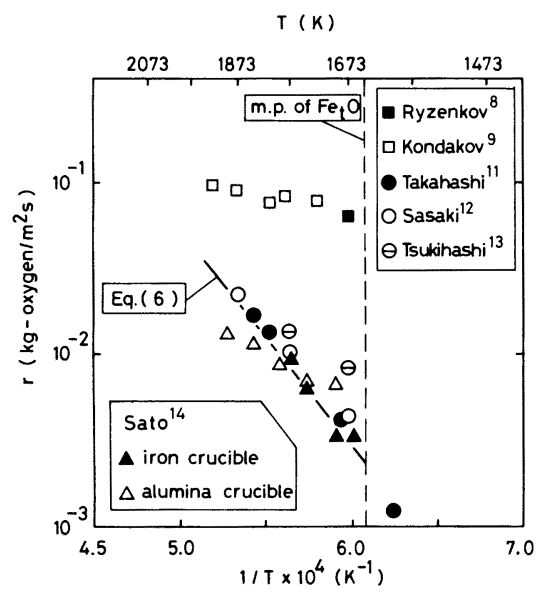

Fig. 1. Temperature dependence of the apparent reduction rate of pure liquid iron oxide with solid carbon.

Table 1. Experimental conditions and the method to determine the rate of reduction of pure liquid iron oxide with solid carbon.

\begin{tabular}{l|c|c|c|c|c|c|c}
\hline \multicolumn{1}{c|}{ Author } & Ref. & Temp. $(\mathrm{K})$ & Crucible & Reductant & Sample $(\mathrm{g})$ & Method $^{*}$ & ${\text { Area } A\left(\mathrm{~cm}^{2}\right)}$ \\
\hline Ryzenkov & 8 & 1673 & Graphite & Crucible & $\mathrm{Fe}_{t} \mathrm{O}(0.3)$ & $\Delta P_{\mathrm{CO}}$ & $1^{5)}$ \\
\hline Kondakov & 9 & $1723 \sim 1923$ & Graphite & Crucible & $\mathrm{Fe}_{\iota} \mathrm{O}(0.3)$ & $\Delta P_{\mathrm{CO}}$ & $1^{5)}$ \\
\hline Kato & 10 & $1385 \sim 1876$ & Graphite & C powder & $\mathrm{Fe}_{\iota} \mathrm{O}(0.2)$ & $\Delta P_{\mathrm{CO}}$ & $?$ \\
\hline Takahashi & 11 & $1603 \sim 1843$ & Graphite & Crucible & $\mathrm{Fe}_{2} \mathrm{O}_{3}(12)$ & $\Sigma \mathrm{CO}$ & 30 \\
\hline Sasaki & 12 & $1673 \sim 1873$ & Graphite & Crucible & $\mathrm{Fe}_{t} \mathrm{O}(10)$ & $\Sigma \mathrm{CO}$ & 10.4 \\
\hline Tsukihashi & 13 & $1673 \sim 1773$ & Graphite & Crucible & $\mathrm{Fe}_{2} \mathrm{O}_{3}(10)$ & $\Sigma \mathrm{CO}$ & 4.52 \\
\hline Sato & 14 & $1693 \sim 1873$ & Iron, $\mathrm{Al}_{2} \mathrm{O}_{3}$ & C rod $(3 \sim 10 \mathrm{~mm} \phi)$ & $\mathrm{Fe}_{t} \mathrm{O}(900)$ & $\Sigma \mathrm{CO}$ & 7 \\
\hline
\end{tabular}

* : $\Delta P_{\mathrm{CO}}=$ mesurement of pressure change by $\mathrm{CO}$ evolution, $\Sigma \mathrm{CO}=$ measurement of gas volume of $\mathrm{CO}$ evolved.

\# : Carbon powder was mixed with $\mathrm{Fe}_{t} \mathrm{O}$ powder in the molar ratio of $1: 4$. 
棒を浸漬して還元実験を行なっているが，還元速度に及 ぼす黒鉛棒の回転数の影響は 0 から $60 \mathrm{rpm}$ の範囲では 認められなかったと報告している.

高温で溶融 $\mathrm{Fe}_{t} \mathrm{O}$ と黒鉛を反応させると, 前述の様に 泡立ちによる固液反応界面積の变化等により, 還元速度 の厳密な評価には非常な困難が予想される. しかしなが ら, Fig. 1 によると, Ryzenkov らと Kondakov らの測 定結果を除き, 諸家の測定結果は非常によく一致してい る. Ryzenkov らと Kondakov らの文献中には反応界面 積は明記されておらず，ここでは相馬 ${ }^{5}$ による推定值， $A=1 \mathrm{~cm}^{2}$ を用いて $r$ を計算した。この様な不確実性に 加え, $\mathrm{Fe}_{t} \mathrm{O}$ 試料の量がわずか $0.3 \mathrm{~g}$ であるため, 還元 反応は約 $10 \mathrm{~s}$ 程度で終了し, 正確な測定が困難であっ たことからこのような差が生じたものと推測される。佐 藤ら ${ }^{14)}$ の研究を除くと, 他はいずれも実験温度に加熱 した黒鉛るつぼに固体酸化鉄を投下して還元させたもの であるが, $\mathrm{Fe}_{t} \mathrm{O}$ を予め溶融させた上で実験に供した佐 藤らの結果とよく一致している．佐藤らは, $\mathrm{Al}_{2} \mathrm{O}_{3}$ るつ ほを用いると, $\mathrm{Fe}_{t} \mathrm{O}$ 中に $\mathrm{Al}_{2} \mathrm{O}_{3}$ が溶解するために還元 速度はやや減少すると報告しているが，Fig. 1 に示すよ うに顕著な差ではない。

前述の様に, Fig. 1 に示した諸家の結果における律速 段階は不明だが, 良い一致を示した高橋ら ${ }^{11)}$, 佐々木 $ら^{12)}$, 月橋ら ${ }^{13)}$, 及び鉄るつぼを用いた佐藤ら ${ }^{14)}$ の結 果を統計処理すると, 全压 $0.1 \mathrm{MPa}, a_{\mathrm{Fe}_{t} \mathrm{O}}=1$ の条件 下における還元速度の実験式として次式が得られる。

$$
\ln r=-30000 / T+12.12
$$

見掛けの活性化エネルギー（以下 $\Delta E$ と略記する）は 約 $250 \mathrm{~kJ} / \mathrm{mol}$ である. ただし，(6)式は本系における 還元速度の代表值を与えるために, 諸家の測定結果を単 純平均したものであって, 特定の反応機構に基づくもの ではない.

\section{$4 \cdot 2$ 溶融 $\mathrm{Fe}-\mathrm{C}$ 合金による逛元（液液系）}

$4 \cdot 2 \cdot 1 \quad$ 還元速度の温度依存性

溶融純酸化鉄の溶融 $\mathrm{Fe}-\mathrm{C}$ 合金による還元速度に関
する研究は過去 7 件 ${ }^{13) ~-19)}$ の報告がなされている．諸家 の実験条件を Table 2 に示す. 本系に関する還元速度 の測定は 1951 年に Dancy ${ }^{15)}$ によって初めてなされた が, 彼の研究は, 今日の溶融還元法を念頭に置いたもの ではない. Dancy に限らず 1970 年代前半までは, 溶融 酸化鉄の還元を高炉，平炉炉床部での反応や酸化鉄によ る溶鉄の脱炭反応に関する基礎研究と位置付けたものが 多く, 時代の変遷が感じられて興味深い.

本系における諸家の測定結果を Fig. 2 に比較して示 す.なお, Fig. 2 中の結果は, 溶鉄中の炭素濃度が 3 mass\% から飽和の場合に得られたものである。また, いずれも得られた還元速度の最大值が代表值として評価 されている. Fig. 2 に示したように, Fig. 1 に示した固 液系の場合と異なり, 測定者間の結果の相違が著しい.

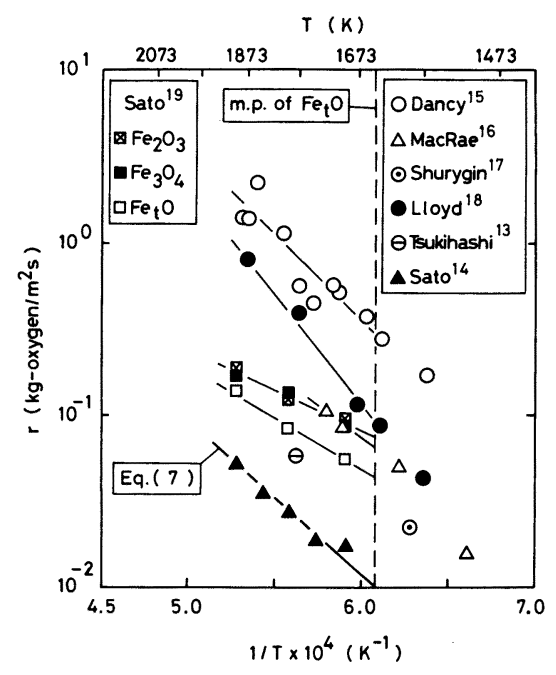

Fig. 2. Temperature dependence of the apparent reduction rate of pure liquid iron oxide with $\mathrm{Fe}-\mathrm{C}$ melts. The carbon content in liquid iron is from 3 mass\% to saturation.

Table 2. Experimental conditions and the method to determine the rate of reduction of pure liquid iron oxide with $\mathrm{Fe}-\mathrm{C}$ melts.

\begin{tabular}{|c|c|c|c|c|c|c|c|c|c|}
\hline Author & Ref. & Temp. (KK) & Crucible & $\begin{array}{c}\text { Wt. of } \\
\mathrm{Fe}^{-} \mathrm{C}(\mathrm{g})\end{array}$ & $\begin{array}{c}{[\operatorname{mass} \% \mathrm{C}]} \\
\text { in } \mathrm{Fe}-\mathrm{C}\end{array}$ & Sample & $\begin{array}{l}\text { Sample } \\
\text { wt. (g) }\end{array}$ & Method ${ }^{*}$ & $\begin{array}{c}\text { Area } A \\
\left(\mathrm{~cm}^{2}\right)\end{array}$ \\
\hline Dancy & 15 & $1573 \sim 1883$ & $\mathrm{MgO}$ & 50 & 4.3 & $\mathrm{Fe}_{t} \mathrm{O}$ & 0.5 & $\Delta P_{\mathrm{CO}}$ & 1 \\
\hline MacRae & 16 & $1513 \sim 1723$ & Graphite & 600 & Sat. & $\mathrm{Fe}_{2} \mathrm{O}_{3}$ & 3 & $\Delta P_{\mathrm{CO}}$ & 3 \\
\hline Shurygin & 17 & $1423 \sim 1593$ & $\mathrm{Al}_{2} \mathrm{O}_{3}$ & $?$ & $?$ & $\mathrm{Fe}_{\iota} \mathrm{O}$ & $?$ & $\Delta P_{\mathrm{CO}}$ & $?$ \\
\hline Lloyd & 18 & $1573 \sim 1873$ & $\mathrm{Al}_{2} \mathrm{O}_{3}$ & 200 & $0.05 \sim 4.15$ & $\mathrm{Fe}_{2} \mathrm{O}_{3}$ & 0.7 & $\Delta P_{\mathrm{CO}}$ & $0.44 \sim 0.54$ \\
\hline Sato & 19 & $1693 \sim 1893$ & $\begin{array}{c}\text { Graphite } \\
\mathrm{Al}_{2} \mathrm{O}_{3}\end{array}$ & 1500 & $\begin{array}{c}\text { Sat. } \\
0.3 \sim \text { sat. }\end{array}$ & $\begin{array}{l}\mathrm{Fe}_{t} \mathrm{O} \\
\mathrm{Fe}_{3} \mathrm{O}_{4} \\
\mathrm{Fe}_{2} \mathrm{O}_{3}\end{array}$ & $\begin{array}{l}20 \\
30 \\
15\end{array}$ & $\Sigma \mathrm{CO}$ & $\begin{array}{l}7.7 \\
8.6 \\
7.3 \\
\end{array}$ \\
\hline Tsukihashi & 13 & 1773 & $\mathrm{Al}_{2} \mathrm{O}_{3}$ & 100 & 3 & $\mathrm{Fe}_{2} \mathrm{O}_{3}$ & 10 & $\Sigma \mathrm{CO}$ & 4.91 \\
\hline Sato & 14 & $1693 \sim 1893$ & $\mathrm{Al}_{2} \mathrm{O}_{3}$ & 1500 & $3.0 \sim$ sat. & $\mathrm{Fe}_{t} \mathrm{O}$ & $20 \sim 70$ & $\Sigma \mathrm{CO}$ & 19.6 \\
\hline
\end{tabular}

* : Keys as in Table 1. 
総括還元速度の絶対値は各測定者間で 1 析以上の差が認 められ，見掛けの活性化エネルギー $\Delta E$ も $100 \mathrm{~kJ} / \mathrm{mol}$ から $250 \mathrm{~kJ} / \mathrm{mol}$ まで約 $150 \mathrm{~kJ} / \mathrm{mol}$ の違いがある.

Fig. 2 に示した結果のうち, 佐藤ら ${ }^{14)}$, Shurygin ら ${ }^{17)}$ の実験を除くといずれも $\mathrm{Fe}-\mathrm{C}$ 合金浴上に室温の固体 酸化鉄を投入して反応を起こさせている. Shurygin ら は, 固体 $\mathrm{Fe}_{t} \mathrm{O}$ の円板を溶融 $\mathrm{Fe}-\mathrm{C}$ 合金中に浸漬して 還元速度を求めているが, 実験温度は全て $\mathrm{Fe}_{\imath} \mathrm{O}$ の融点 以下である。また, Dancy, MacRae ${ }^{16)}$ 及び Lloyd ら ${ }^{18)}$ も, 一部 $\mathrm{Fe}_{t} \mathrm{O}$ の融点以下の温度で実験を行なっている が, いずれも $\ln r$ と $1 / T$ の間にはほほ直線関係が成立 し, $\mathrm{Fe}_{t} \mathrm{O}$ の融点における還元速度の不連続性は認めら れない. $\mathrm{Fe}_{t} \mathrm{O}$ の融点以上の温度においても, 溶鉄上に 投入された固体酸化鉄は, 反応末期を除いて固体状態の ままで還元されているという報告 ${ }^{16) 19) か ゙ あ る . ~}$

Lloyd らは, 酸化鉄試料を予め余熱しておく事により 還元速度が低下すると報告している．また MacRae は， 酸化鉄が溶融状態になると, 還元速度は遅くなると述べ ている.これらに対して佐藤ら ${ }^{14)}$ は, 炭素飽和溶鉄の 直上に保持された鉄製容器中で $\mathrm{Fe}_{t} \mathrm{O}$ を予め溶融させた 後に溶鉄上に添加した. Fig. 2 を見ると, 唯一反応初期 状態から $\mathrm{Fe}_{t} \mathrm{O}$ が溶融状態に保たれている佐藤ら ${ }^{14)}$ の結 果が最も低值を示しており，先の Lloyd ら, MacRae の指摘と一致している. ただし，溶融 $\mathrm{Fe}_{t} \mathrm{O}$ の還元速度 が固体 $\mathrm{Fe}_{t} \mathrm{O}$ のそれよりも遅いとする説にはなお疑問が 残る.

以上のように，佐藤ら ${ }^{14)}$ の実験を除けば還元途中の 酸化鉄試料の状態は, 固体か液体か必ずしも明確ではな い. そこで本稿では, 以後本系における還元速度として,

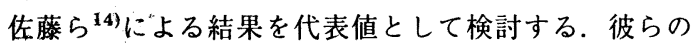
結果, すなわち全圧 $0.1 \mathrm{MPa}, a_{\mathrm{Fe}_{\imath} \mathrm{O}}=a_{\mathrm{Fe}}=a_{\mathrm{C}}=1$, の条件における還元速度の実験式として( 7$)$ 式が得られ る.

$\ln r=-20300 / T+7.79$.

( 7 )式より， $\Delta E$ は約 $170 \mathrm{~kJ} / \mathrm{mol}$ である.ただし，先 の( 6 )式の場合と同様に，（ 7 )式は特定の反応機構に基 づくものではない.

$4 \cdot 2 \cdot 2$ 還元速度の溶鉄中炭素濃度依存性

純酸化鉄の還元速度と溶鉄中炭素濃度の関係を明らか にすることは, 反応機構を考察する上で重要な手掛りを 与えるものと考えられるが，これまで 2,3 の測定例し

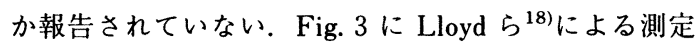
結果を示す．Lloyd らは，還元速度に及ぼす溶鉄中炭素 濃度の影響は約 0.2 mass\% 以上では顕著ではないが, それ以下では炭素濃度の減少と共に速度は減少すると述 ベている, 佐藤ら ${ }^{19)} も$ Lloyd らと同様の結果を得てい る.またこの傾向は，本系の逆の反応である $\mathrm{Fe}_{t} \mathrm{O}$ によ る溶鉄の脱炭反応においても認められている.しかし，

Fig. 3 中に同時に示すように，後に佐藤らは文献 14）

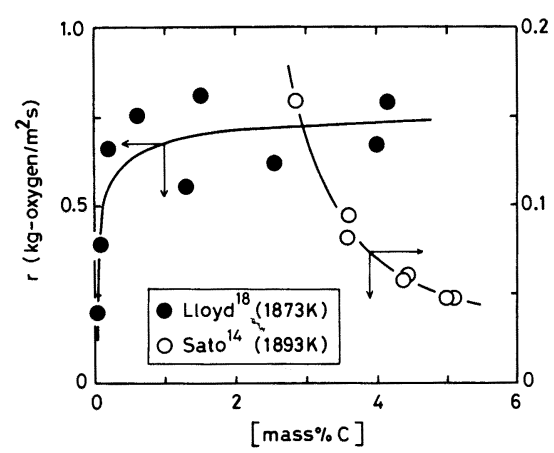

Fig. 3. Effect of carbon content in liquid iron on the apparent reduction rate of pure liquid iron oxide with $\mathrm{Fe}-\mathrm{C}$ melts.

において逆に還元速度と炭素濃度は反比例関係にあると 報告している.

( 2 )式に従えば, 酸化鉄の活量は 1 で一定なので,一 定温度下では還元速度は反応の駆動力である炭素活量に 比例して増加すると思われる. 佐藤ら ${ }^{14)}$ は, 還元速度 が炭素活量に対して反比例関係になった理由については 全く言及しておらず，詳細は不明である。

\section{$4 \cdot 3$ ガスによる還元（気液系）}

溶融酸化鉄のガスによる還元は，反忍界面積の正確な 評価が可能な事から, 先の固液, 液液系に比べて還元速 度の評価や反応機構の解明がはるかに谷易であるが，本 系に関する研究例は非常に少ない. しかし, 反応の律速 段階に関しては，かなり厳密に検討されている，なお， 本系における実験では, 固液, 液液系の実験の場合と異 なり, 試料の初期条件は全て溶融状態になっている.

本系は， $\mathrm{H}_{2}$ による還元と $\mathrm{CO}$ による還元に大別され る. 本系における諸家の実験条件を Table 3 に一括し て示す.

\section{$4 \cdot 3 \cdot 1 \quad \mathrm{H}_{2}$ による還元}

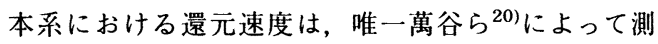
定されている．萬谷らは, 純 $\mathrm{Fe}_{t} \mathrm{O}$ 試料を鉄るつぼ中で 溶融させているが, 鉄るつぼを用いることで試料の初期 組成を鉄飽和の条件として規定でき，酎火物からの污染 も防止できる特徴がある. 彼らは, 還元速度 $r$ は全実 験範囲で還元ガス中の $\mathrm{H}_{2}$ 分圧の 1 次に比例し, (8)式 の関係が成立する事を見出している.

$$
r=k_{a} \cdot P_{\mathrm{H}_{2}}\left(k_{a}: \mathrm{kg} \text {-oxygen } / \mathrm{m}^{2} \mathrm{~s} \cdot \mathrm{Pa}\right) \cdots
$$

Fig. 4 は, 萬谷らにより測定された $(8)$ 式で定義され る見掛けの還元速度定数 $k_{a}$ のガス流量依存性である. 彼らは, Fig. 4 中の領域 I のガス流量域では, $k_{a}$ がガ ス流量 $V$ の $2 / 3$ 乗に比例する事, $V$ が一定でも混合ガ スの種類によって $k_{a}$ が異なる事等を理由に, 反応はガ ス側物質移動律速であると結論した。しかし，領域 II の高ガス流量域では化学反応とガス側物質移動の混合律 
Table 3. Experimental conditions and the method to determine the rate of reduction of pure liquid iron oxide with $\mathrm{H}_{2}$ or $\mathrm{CO}$.

\begin{tabular}{|c|c|c|c|c|c|c|c|c|c|}
\hline Author & Ref. & \begin{tabular}{|c|} 
Temp. \\
(K)
\end{tabular} & Crucible & Sample (g) & Reductant & $\begin{array}{c}\text { Flow rate } \\
(1 / \mathrm{min})\end{array}$ & $\begin{array}{c}\text { Gas composition } \\
(\mathrm{atm})\end{array}$ & Method* & $\begin{array}{l}\text { Area } A \\
\left(\mathrm{~cm}^{2}\right)\end{array}$ \\
\hline Ban-ya & 20 & \begin{tabular}{|l|}
1673 \\
1723 \\
\end{tabular} & Iron & $\begin{array}{l}\mathrm{Fe}_{t} \mathrm{O} \\
(3.5)\end{array}$ & $\begin{array}{l}\mathrm{H}_{2}-\mathrm{N}_{2}, \mathrm{H}_{2}-\mathrm{Ar} \\
\mathrm{H}_{2}-\mathrm{He}\end{array}$ & $0.4 \sim 28$ & $P_{\mathrm{H}_{2}}=0.002 \sim 0.1$ & $\Delta \mathrm{WS}$ & 2.45 \\
\hline Kato & 21 & 1873 & $\mathrm{Al}_{2} \mathrm{O}_{3}$ & $\underset{(?)}{\mathrm{Fe}_{l} \mathrm{O}}$ & $\mathrm{CO}$ & $0.9 \sim 16$ & $P_{\mathrm{CO}}=1$ & $\Sigma \mathrm{CO}$ & 7.1 \\
\hline Tsukihashi & 22 & \begin{tabular}{l|}
1723 \\
1873 \\
\end{tabular} & None ${ }^{\#}$ & $\underset{(1 \sim 3)}{\mathrm{Fe}_{t} \mathrm{O}}$ & $\mathrm{CO}$ & $0.7 \sim 3.7$ & $P_{\mathrm{CO}}=1$ & C.A. & $2 \times 10^{-58}$ \\
\hline Nagasaka & 23 & \begin{tabular}{|l|}
1673 \\
1723 \\
\end{tabular} & Iron & $\begin{array}{l}\mathrm{Fe}_{t} \mathrm{O} \\
(3.5)\end{array}$ & $\mathrm{CO}-\mathrm{CO}_{2}-\mathrm{Ar}$ & $0.1 \sim 3.8$ & $\begin{array}{l}P_{\mathrm{CO}}=0.02 \sim 0.84 \\
\mathrm{CO}_{2} / \mathrm{CO}=0 \sim 0.24\end{array}$ & $\Delta \mathrm{WS}$ & 2.45 \\
\hline Koch & 24 & 1823 & $\mathrm{Al}_{2} \mathrm{O}_{3}$ & $\begin{array}{c}\mathrm{Fe}_{e_{t}} \mathrm{O} \\
(?)\end{array}$ & $\mathrm{CO}-\mathrm{CO}_{2}$ & $0.1 \sim 1.7$ & $?$ & G.A. & $?$ \\
\hline
\end{tabular}

* : $\Delta \mathrm{WS}=$ measurement of weight change of the sample, C.A. $=$ chemical analysis of the sample, G.A. $=$ analysis of gas evolved, other keys as in Table 1 .

\# : Reduction was made in $\mathrm{CO}$ gas conveyed system.

$\$$ : Estimated by the authers. Tsukihashi et al. determined the value of $A$ more exactly.

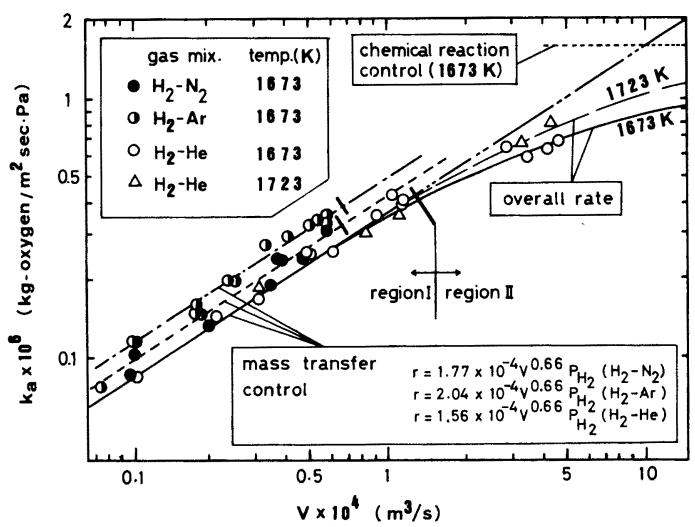

Fig. 4. Effect of gas flowrate on the apparent reduction rate of pure liquid iron oxide with $\mathrm{H}_{2}$ ( after Ban-ya et $a l^{20)}$ ).

速であるとし, 解析的に化学仪応速度を推定している.

Fig. 5 は, 求められた化学反応速度とガス組成の関係で ある。この汹より，還元速度は温度一定の条件ではガス 組成の関数として次式の形式で表わされることがわか る.

$$
r=k_{a}\left(P_{\mathrm{H}_{2}}-P_{\mathrm{H}_{2} \mathrm{O}} / K_{\mathrm{H}}{ }^{\prime}\right)
$$

ここで， $K_{\mathrm{H}}{ }^{\prime}$ は溶融 $\mathrm{Fe}_{t} \mathrm{O}$ と平衡する気相中の $\mathrm{H}_{2} \mathrm{O} / \mathrm{H}_{2}$ 比である。萬谷ら以外に本系の還元速度を直接測定した 例はないが, Fig. 5 より $1673 \mathrm{~K}, P_{\mathrm{H}_{2}}=0.1 \mathrm{MPa}(1 \mathrm{~atm})$ での還元速度は $1.6 \times 10^{-1}\left(\mathrm{~kg}\right.$-oxygen $\left./ \mathrm{m}^{2} \mathrm{~s}\right)$ と推定さ れる.この值は還元速度としてはかなり速く，Fig. 4 に 示したようにより精度の高い直接測定を行なうためには ガス側物質移動の影響を何らかの形で取除く努力が必要 となる.

$4 \cdot 3 \cdot 2$ CO による還元

本系に関しては，過去 4 件 $^{21) ~ 24)}$ の報告がある。 なお

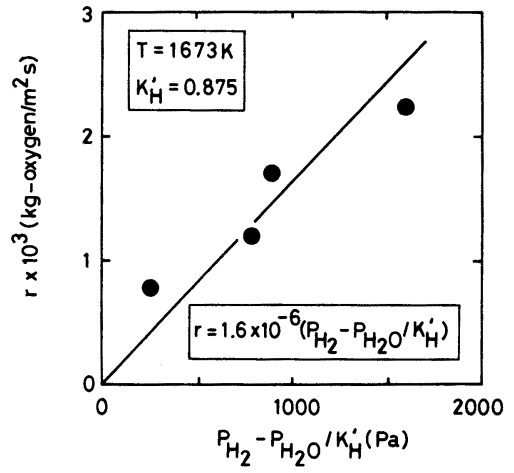

Fig. 5. Effect of the gas composition on the apparent reduction rate of pure liquid iron oxide with $\mathrm{H}_{2}$ (after Ban-ya et $a l^{20)}$ ).

Koch $5^{24)}$ の文献は，実験デー夕の記述が不十分であり， 速度の比較は困難であった。諸家により測定された本系 における還元速度の温度依存性を Fig. 6 に示す。これ らはいずれも気液界面における化学反応速度として評価

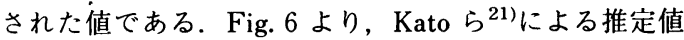
を除けば，いずれもよく一致していることがわかる。

Kato $ら^{21)}$ は，ガス流量 $V=0.9 \sim 16 \mathrm{l} / \mathrm{min}$ の全実験 範囲内で還元速度が $V$ に依存する事から，反応はガス 側物質移動律速であり, 化学反応速度は $r=2.6 \times 10^{-1}$ $\mathrm{kg}$-oxygen $/ \mathrm{m}^{2} \mathrm{~s}$ 以上であると推定した。相馬 ${ }^{5)}$ は後に自 らの結果に疑問を示し, $r=4.9 \times 10^{-3}$ という值を再 提案しているが, 真の值は両者の中間にあると予想して いる.

月橋ら ${ }^{22)}$ は, $\mathrm{Fe}_{t} \mathrm{O}$ 微粉を $\mathrm{CO}$ を搬送ガスとして抵抗 炉内へ吹き込んで液滴状態で還元し, 試料の組成変化か ら還元速度を求めた。 Ranz-Marshall の式に従えば, 約 $25 \mu \mathrm{m}$ の微粒子を用いれば，ガス側物質移動抵抗を無視 


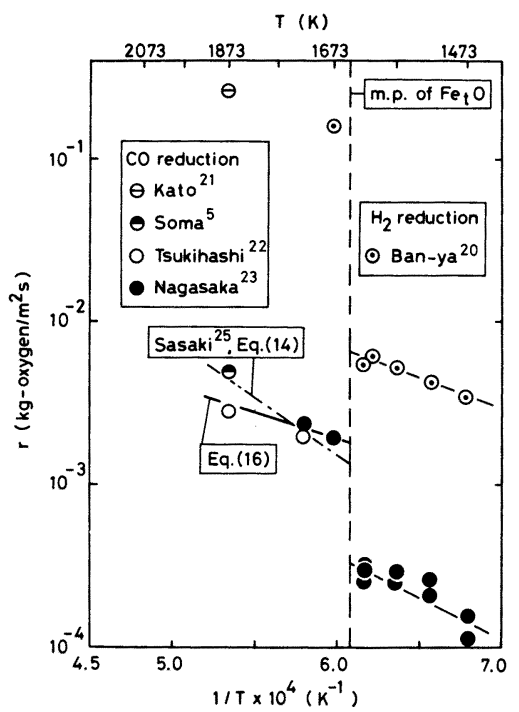

Fig. 6. Temperature dependence of the apparent reduction rate of pure liquid iron oxide with $\mathrm{H}_{2}$ or $\mathrm{CO}$ at $P_{\mathrm{H}_{2}}, P_{\mathrm{CO}}=0.1 \mathrm{MPa}$.

できるほど小さくできるので，還元は化学仪応によって 律速されると考えられる. 実験後の試料断面を観察した ところ, 生成した金属鉄は全て溶融 $\mathrm{Fe}_{t} \mathrm{O}$ 内部に球状の 核のような形で存在していた。 すなわちこの事は, 生成 した鉄はただちに溶融 $\mathrm{Fe}_{t} \mathrm{O}$ 内部に沈降し，試料表面は 常に純 $\mathrm{Fe}_{t} \mathrm{O}$ に覆われている事を意味している.

長坂ら ${ }^{23)}$ は, 鉄るつほ中の純溶融 $\mathrm{Fe}_{t} \mathrm{O}$ 表面に CO- $\mathrm{CO}_{2}-\mathrm{Ar}$ 混合ガスを吹付けて還元し，ガス流量が $3 \mathrm{l} / \mathrm{min}$ 以上で還元速度がガス流量に依存しないことな どから化学又応律速であるとした．Fig. 7 は彼らが測定 した $1673 \mathrm{~K}$ における還元速度とガス組成の関係を示し たものである。この結果より，還元反応速度は(9)式と 同じ形式の (10)式で与えられることがわかる.

$$
r=k_{a}\left(P_{\mathrm{CO}}-P_{\mathrm{CO}_{2}} / K_{\mathrm{C}}{ }^{\prime}\right)
$$

$k_{a}=\exp (-7300 / T-13.49)\left(\mathrm{kg}-\right.$ oxygen $\left./ \mathrm{m}^{2} \mathrm{~s} \cdot \mathrm{Pa}\right)$

ここで $K_{\mathrm{C}}^{\prime}$ は, 溶融 $\mathrm{Fe}_{t} \mathrm{O}$ と平衡する気相中の $\mathrm{CO}_{2} / \mathrm{CO}$ 比である. なお，彼らの研究においても還元初期に生成 した金属鉄は $\mathrm{Fe}_{t} \mathrm{O}$ 中へ沈降している事が観察されてい る.

一方, Sasaki ら ${ }^{25)}$ は同位体 ${ }^{14} \mathrm{CO}_{2}$ を含む $\mathrm{CO}-\mathrm{CO}_{2}$ 混合ガスを用いて, 溶融純 $\mathrm{Fe}_{t} \mathrm{O}$ の $\mathrm{CO}_{2}$ による酸化速 度を測定した，彼らの用いた同位体交換法では，平衡条 件下で測定が行なわれるため, 界面における(12)式の化 学反応速度を測定できる特徴がある.

$\mathrm{CO}_{2}(\mathrm{~g})=\mathrm{CO}(\mathrm{g})+\mathrm{O}\left(\right.$ in liquid $\left.\mathrm{Fe}_{t} \mathrm{O}\right)$

(12)式の正度応速度定数 $\vec{k}_{12}$ は, 気相中の $\mathrm{CO}_{2} / \mathrm{CO} の$

-1 乗に比例し, 温度の上昇と共に増加する。これら

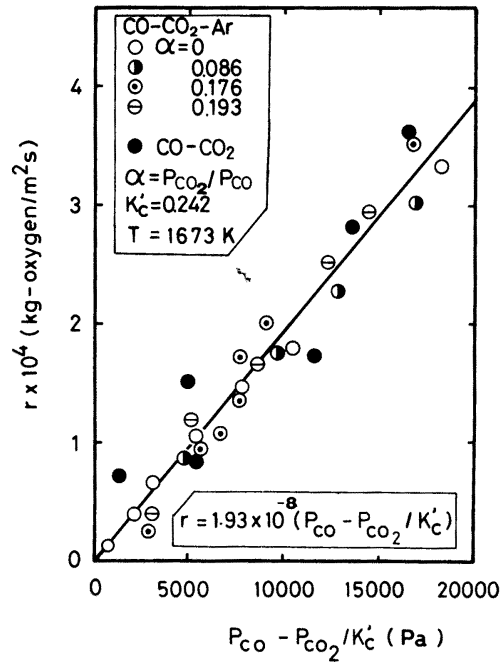

Fig. 7. Effect of the gas composition on the apparent reduction rate of pure liquid iron oxide with CO ( after Nagasaka et al. ${ }^{23)}$ ).

の結果より，彼らは(12)式の速度式を(13)式で与えた $r=\overrightarrow{k_{12}}\left\{P_{\mathrm{CO}_{2}} /\left(P_{\mathrm{CO}_{2}} / P_{\mathrm{CO}}\right)_{\text {eq. }}-P_{\mathrm{CO}}\right\}$

$\overrightarrow{k_{12}}=\exp (-15900 / T-8.48)\left(\mathrm{kg}-\right.$ oxygen $\left./ \mathrm{m}^{2} \mathrm{~s} \cdot \mathrm{Pa}\right)$

(9)，(13)式より，両者は同一形式であることがわかる. 平衡状態では (12)式の正, 逆皮心速度, すなわち酸化速 度と還元速度は等しく，(15)式の関係がある ${ }^{25)}$.

$\overleftarrow{k_{12}}=k_{\mathrm{C}} \cdot \overrightarrow{k_{12}}$

ここで， と (15)式より求められる $\overleftarrow{k_{12}}$ ，すなわち還元速度を Fig.

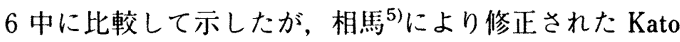
$ら^{21)}$ の值, 月橋 ${ }^{22)}$, 長坂ら ${ }^{23)}$ の值と非常に良く一致 している.この事は, 溶融純 $\mathrm{Fe}_{t} \mathrm{O}$ の $\mathrm{CO}-\mathrm{CO}_{2}$ 混令ガ スによる酸化と還元文応の律速段階は同じであることを 示唆している．後述するように, $\mathrm{Fe}_{t} \mathrm{O}$ に他の酸化物を 添加した多元系においても，CO 還元速度と同位体交換 法による酸化速度の結果は極めてよく一致しており，反 応機構を解明する上で重要な手掛りを与えている.

Fig. 6 より, $P_{\mathrm{CO}}=0.1 \mathrm{MPa}, \quad a_{\mathrm{Fe}, \mathrm{O}}=a_{\mathrm{Fe}}=1$ にお ける溶融純 $\mathrm{Fe}_{t} \mathrm{O}$ O $\mathrm{CO}$ による還元速度は(16)式で与 えられる。

$\ln r=-7300 / T-1.89$

(16)式は，化学反応過程に基づく速度式であると考えら れる。また(16)式より， $\Delta E$ として約 $60 \mathrm{~kJ} / \mathrm{mol}$ が得ら れるが, この值は, 固液系や液液系の場合に比べて小さ な值である.

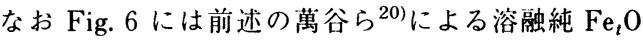
の $\mathrm{H}_{2}$ による還元速度の值を比較のために示したが, $\mathrm{H}_{2}$ 還元速度は $\mathrm{CO}$ 還元速度より約 2 桁大きいことがわか 


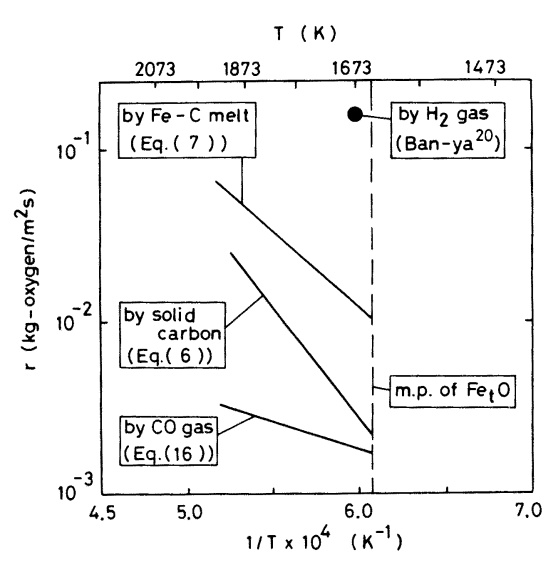

Fig. 8. Comparison of the apparent reduction rate of pure liquid iron oxide with solid carbon, $\mathrm{Fe}-\mathrm{C}$ melts, $\mathrm{H}_{2}$ and $\mathrm{CO}$.

る. また, 液体と周体の $\mathrm{Fe}_{t} \mathrm{O}$ の還元速度の違いを示す 一例として, 萬谷ら ${ }^{20) 23)} に よ る$ 固体 $\mathrm{Fe}_{t} \mathrm{O}$ の $\mathrm{H}_{2}$ 及び CO 還元速度を Fig. 6 中に示した. 萬谷らによれば, 固体状態に比べて溶融状態では約 1 桁大きな還元速度が 得られている.

\section{$4 \cdot 43$ 種類の還元方式における掼元速度の比較}

Fig. 8 は，Fig. 1，2，6に示した溶融純酸化鉄の還元 速度の温度依存性を三つの還元方式の間で比較したもの である。四中の各系の結果は（6)，（7)，(16)式及び萬 谷ら ${ }^{20)}$ の実測值より与えられる值である。この結果を 見ると, 一定温度では $\mathrm{H}_{2}$ 還元速度が最も速く，次いで 溶融 $\mathrm{Fe}-\mathrm{C}$ 合金による液液系, 固体炭素による固液系, COによる気液系の順になっている。（3)式は吸熱反応 である事が知られているが, Fig. 8 の結果より，熱的な 余裕があれば $\mathrm{H}_{2}$ による非常に速い還元速度は実用的に 大きな魅力である. $\mathrm{CO} に よ る$ 還元速度は, 固液系とオー ダー的には近いが，4者間では最も低い值である.

ところで, 溶融 $\mathrm{Fe}^{-\mathrm{C}}$ 合金と固体炭素を用いた場合 では, どちらが還元速度が速いかという疑問は, 溶融 $\mathrm{Fe}-\mathrm{C}$ 合金浴に鉄鉣石を吹き込むのと溶融 $\mathrm{Fe}_{t} \mathrm{O}$ 浴に炭 材を吹き込むのとではどちらが速度的に有利か，という 実用的観点からよく議論される. Fig. 8, あるいは Fig. 1 と Fig. 2 を比較すればわかるように, 実験的には明 らかに液液系の方が 1 桁から 2 杵速い還元速度が得られ ている. 還元剤として固体炭素と炭素飽和溶鉄を用いた 場合，（1)式と( 2 )式を比較するとわかるように，仮に 界面積が等しいとすれば，生成する鉄の活量が低くても よい分だけ溶融 $\mathrm{Fe}-\mathrm{C}$ 合金による還元の方が有利であ ると予想される。しかし、これまでにも液液系における 還元が固液系における還元より速い理由については, 様々な意見7)が述べられているが，真の理由は不明のま まであり，今後明らかにしてゆく必要がある課題のひと
つと考えられる.

\section{5. 溶融スラグ中 $\mathrm{Fe}_{t} \mathrm{O}$ の還元速度}

溶融 $\mathrm{Fe}_{t} \mathrm{O}$ の還元速度に及ぼす共存酸化物の影響を明 らかにすることは, 還元反応機構を解明する上で不叮欠 である事はいうまでもない，また，実際の溶融還元プロ セスにおいても，適切なスラグ組成を選択する事は， $\mathrm{Fe}_{t} \mathrm{O}$ の還元速度の制御と耐火物保護の上で重要であ る.

前述の純 $\mathrm{Fe}_{t} \mathrm{O}$ の場合には，還元途中でも $\mathrm{Fe}_{t} \mathrm{O}$ の活 量は常に 1 であり，還元速度は一定值を示すと考えられ た.しかし多元系スラグの場合は，還元の進行と共に $\mathrm{Fe}_{t} \mathrm{O}$ 濃度が減少し, $\mathrm{Fe}_{t} \mathrm{O}$ の活量は経時的に変化する. またこのため, スラグ中の物質移動の影響も関与する叮 能性がある．更にスラグの泡立ち挙動も組成に依存する と考えられるので, 測定される総括還元速度のスラグ組 成依存性を支配している要因を明確にする事は難しい. 各研究者によって実験的工夫はなされているが，上記の 要因が還元機構の解明を一層困難にしている.

\section{$5 \cdot 1$ 固体炭素による還元（固液系）}

本系に関する研究は比較的多く, 過去 14 件 12)17)26) 38) の報告例があるが，そのスラグ組成，実験温度は大きく 異なっている．諸家の実験条件を Table 4 に示す.

$5 \cdot 1 \cdot 1 \quad \mathrm{Fe}_{t} \mathrm{O}-\mathrm{SiO}_{2}, \mathrm{Fe}_{t} \mathrm{O}-\mathrm{CaO} 2$ 元系スラグ

本 2 元系スラグの固体炭素による還元速度は, 過去 6

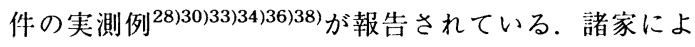
り測定された還元速度と $\mathrm{SiO}_{2}$ 濃度の関係を Fig. 9 に 示す. Fig. 9 中の $\mathrm{SiO}_{2}$ 濃度が 0 における值は, $(6)$ 式 で示した純 $\mathrm{Fe}_{t} \mathrm{O}$ における值である。また佐々木ら ${ }^{36)} の$ 結果は, 還元にともなう試料の組成変化を考慮して本研 究で再計算した值である.

Davies ら ${ }^{34)}$ は, 還元速度は $\mathrm{SiO}_{2}$ 濃度が 5 から 40 mass\%までは $\mathrm{SiO}_{2}$ 濃度に依存せず, 一定であると報 告している. 彼らの結果は, 前述した純 $\mathrm{Fe}_{t} \mathrm{O}$ の還元速 度と非常によく一致している。 これに対して Ershov $5^{28)}$, 須賀田ら ${ }^{33)}$, 佐々木ら ${ }^{36)}$, 原ら ${ }^{38)}$ は, いずれも $\mathrm{SiO}_{2}$ 濃度の増加と共に還元速度が低下する結果を得て いる. $1673 \mathrm{~K} に$ におる須賀田らと佐々木らの結果はよ く一致している. Krainer $5^{30)}$ も還元速度は $\mathrm{SiO}_{2}$ 濃度 の増加と共に減少すると報告しているが, 還元速度の導 出過程が明記されておらず, 結果の比較はできなかった.

Ershov ら，須賀田らは，スラグに黒鉛棒を浸漬して 還元を行なっているが, Fig. 9 に示したスラグ組成範囲 内では, 還元速度は黒鉛棒の回転数に依存しない事から, 化学反応律速であるとしている.これに対して Krainer らは, 還元速度はスラグ中の $\mathrm{Fe}_{t} \mathrm{O}$ 濃度の 1 次に比例す る事から, $\mathrm{CO} に よ る ~ \mathrm{Fe}_{t} \mathrm{O}$ の還元反応 $((4)$ 式) が律 速であると結論した。 また佐々木らは, $\mathrm{SiO}_{2}$ 濃度が 20 mass\% 以上では物質移動律速である可能性を示唆して 
Table 4. Experimental conditions and the method to determine the rate of reduction of $\mathrm{Fe}_{t} \mathrm{O}$ in liquid slags with solid carbon.

\begin{tabular}{|c|c|c|c|c|c|c|c|c|c|c|}
\hline Author & Ref. & Temp. (K) & Crucible & Reductant & Slag system $\#$ & $\begin{array}{l}\text { Slag wt. } \\
(\mathrm{g})\end{array}$ & $\underset{\text { (in wt.) }}{\mathrm{CaO} / \mathrm{SiO}_{2}}$ & $\begin{array}{c}\mathrm{Fe}_{t} \mathrm{O} \\
\text { (mass\%) }\end{array}$ & Method* & $\begin{array}{c}\text { Area } A \\
\left(\mathrm{~cm}^{2}\right)\end{array}$ \\
\hline Philbrook & 26 & 1703,1843 & Graphite & Crucible & FCSA & 65,100 & 1.24 & $0.3 \sim 5$ & C.A. & $13-56$ \\
\hline Kondakov & 27 & $?$ & $\mathrm{ZrO}_{2}$ & C rod & FCSA & $?$ & $0.6 \sim 1.4$ & $2 \sim 8$ & $\Delta \mathrm{WS}$ & $?$ \\
\hline Ershov & 28 & $1773 \sim 2073$ & $\mathrm{ZrO}_{2}$ & C rod & FS, FCS, FCSA & $?$ & $0.3 \sim 1.7$ & $10 \sim 60$ & $\Delta \mathrm{WG}$ & $?$ \\
\hline Shavrin & 29 & $1623 \sim 1753$ & $\mathrm{Al}_{2} \mathrm{O}_{3}$ & C sphere & FCSAM & $?$ & $0.9 \sim 1.12$ & $5.3 \sim 19.6$ & $\Sigma \mathrm{CO}$ & 7.1 \\
\hline Shurygin & 17 & $1423 \sim 1793$ & $\mathrm{Al}_{2} \mathrm{O}_{3}$ & $\mathrm{C}$ disk & FCSA & $?$ & 1.0 & $1.0 \sim 9.1$ & $\Delta P_{\mathrm{CO}}$ & $?$ \\
\hline Krainer & 30 & $1373 \sim 1773$ & $\begin{array}{c}\text { Graphite } \\
\text { Coke }\end{array}$ & Crucible & $\mathrm{FS}, \mathrm{FCS}, \mathrm{FCSA}$ & $?$ & $0,1.1$ & $25 \sim 70$ & $\Delta \mathrm{WS}$ & $?$ \\
\hline Tarby & 31 & 1773,1848 & Graphite & Crucible & FCSA & $100 \sim 300$ & $6.3,1.25$ & $?$ & C.A. & $57 \sim 83$ \\
\hline Fun & 32 & $1923 \pm 35$ & $\mathrm{MgO}$ & $\mathrm{C}$ rod & FCSAM & $1345 \sim 2310$ & $1.2 \pm 0.3$ & $14 \sim 45$ & C.A. & $8.2 \sim 14.9$ \\
\hline Sugata & 33 & $1623 \sim 1723$ & Iron & $C$ rod & $\begin{array}{l}\text { FS, FCS, } \\
\text { FSA, FSM }\end{array}$ & 200,280 & $0.17 \sim 0.68$ & $22.2 \sim 61.0$ & C.A. & $22.4 \sim 38.1$ \\
\hline Davies & 34 & $1673 \sim 1773$ & $\begin{array}{c}\text { Graphite } \\
\text { Coke }\end{array}$ & Crucible & FS, FCS & $10 \sim 120$ & $0.11,0.59$ & $63 \sim 97$ & C.A. & $6.8 \sim 55.7$ \\
\hline Borgianni & 35 & $1273 \sim 1723$ & Graphite & Fine coke & $\mathrm{FC}, \mathrm{FCS}$ & 100 & $0.2 \sim 2.2$ & 80 & $\Delta \mathrm{WS}$ & $?$ \\
\hline Sasaki & $\begin{array}{l}12 \\
36 \\
\end{array}$ & $1673 \sim 1873$ & Graphite & Crucible & $\mathrm{FS}, \mathrm{FC}, \mathrm{FCS}$ & $11.1 \sim 14.7$ & $0.5 \sim 2.0$ & $70 \sim 90$ & $\Sigma \mathrm{CO}$ & $25 \sim 30$ \\
\hline Sato & 37 & $1693 \sim 1893$ & Graphite & Crucible & FCSA & 40 & $0.37 \sim 1.81$ & $2 \sim 30$ & $\Sigma \mathrm{CO}$ & 11.6 \\
\hline Hara & 38 & $1573 \sim 1673$ & $\mathrm{Al}_{2} \mathrm{O}_{3}$ & C rod & FS, FCS & $48 \sim 51$ & $0.5,1.0$ & 70,75 & $\Sigma \mathrm{CO}$ & $?$ \\
\hline
\end{tabular}

\#: $\mathrm{F}=\mathrm{Fe}_{t} \mathrm{O}, \mathrm{C}=\mathrm{CaO}, \mathrm{S}=\mathrm{SiO}_{2}, \mathrm{~A}=\mathrm{Al}_{2} \mathrm{O}_{3}, \mathrm{M}=\mathrm{MgO}$.

*: $\Delta \mathrm{WG}=$ Measurement of the weight change of graphite rod. Other keys as in Table 1 and Table 3.

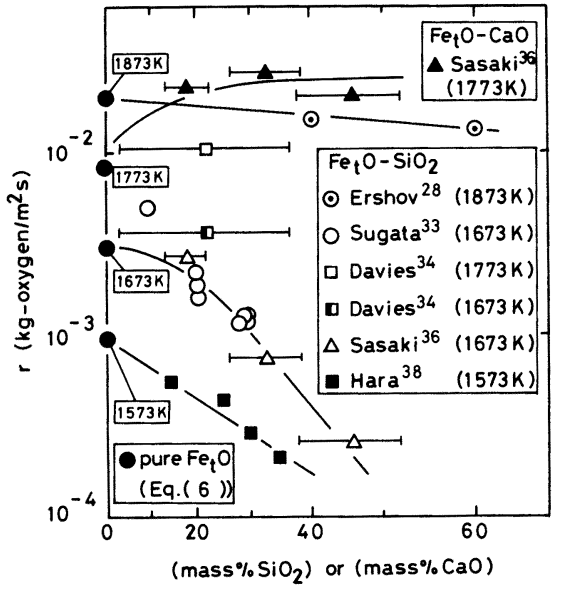

Fig. 9. Effect of $\mathrm{SiO}_{2}$ or $\mathrm{CaO}$ on the apparent reduction rate of $\mathrm{Fe}_{t} \mathrm{O}$ in liquid $\mathrm{Fe}_{t} \mathrm{O}-\mathrm{SiO}_{2}$ or $\mathrm{Fe}_{t} \mathrm{O}-\mathrm{CaO}$ binary slags with solid carbon.

おり, 反応機構に対する一致した見解は得られていない. 本 2 元系スラグの還元速度の温度依存性については,

Davies ら, 須賀田ら, Shalimov $ら^{6)}$ が, 純 $\mathrm{Fe}_{t} \mathrm{O}$ の場 合に近い 210 から $250 \mathrm{~kJ} / \mathrm{mol}$ の活性化エネルギー $\Delta E$ を得ている. Krainer らは, るつほ材としてコークスと 黒鉛を用いた場合で, それぞれ $170,125 \mathrm{~kJ} / \mathrm{mol}$, 佐々 木らは約 $100 \mathrm{~kJ} / \mathrm{mol} の \Delta E$ を報告しているが，原らは これらより小さな約 $55 \mathrm{~kJ} / \mathrm{mol}$ を得ている.
$\mathrm{Fe}_{t} \mathrm{O}-\mathrm{CaO} 2$ 元系スラグの固体炭素による還元速度

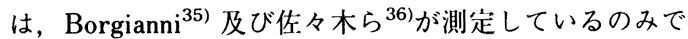
ある、ただし，Borgianni の実験では，反応界面積の評 価が困難なため, 結果の比較検討はできなかった。

佐々木らによって測定された還元速度の $\mathrm{CaO}$ 濃度依 存性を前出の Fig. 9 中に示す.なお, 彼らは本系スラ グの還元においては泡立ちは顕著ではなかったと述べて いるので，界面積を純 $\mathrm{Fe}_{t} \mathrm{O}$ の場合と同じ $10 \mathrm{~cm}^{2}$ とし た. 彼らの結果によれば, $\mathrm{Fe}_{t} \mathrm{O}$ に $\mathrm{CaO}$ を添加すると Fig. 9 に示すように還元速度は増加するが, $\mathrm{CaO}$ 濃度 が 10 mass\% 以上では，還元速度はほぼ一定值になって いる.また, $\Delta E$ は非常に小さく, 約 $10 \mathrm{~kJ} / \mathrm{mol}$ の値が 得られている.これに対し Borgianni は, 約 $65 \mathrm{~kJ} / \mathrm{mol}$ の $\Delta E$ を報告している.

\section{$5 \cdot 1 \cdot 2$ 多元系スラグ中の $\mathrm{Fe}_{t} \mathrm{O}$ の還元速度}

( 1 ) 還元速度の $\mathrm{Fe}_{t} \mathrm{O}$ 濃度依存性

本系に関しては，14 件の報告例 ${ }^{12) 17) 26) ~ 35) 37) 38) か ゙ あ ~}$ る.このうち $\mathrm{Fe}_{t} \mathrm{O}-\mathrm{SiO}_{2}-\mathrm{CaO} 3$ 元系スラグを対象とし たのは 7 例であり, その他の実験ではこの 3 元系に $\mathrm{Al}_{2} \mathrm{O}_{3}$ や $\mathrm{MgO}$ 等を含んだ 4 元系以上のスラグを対象に している．このように，スラグ組成が研究者によって異 なるため,ここでは 3 元系以上のスラグ系をスラグ中塩 基度 ( $\mathrm{CaO}$ と $\mathrm{SiO}_{2}$ の重量比), $\mathrm{Fe}_{\imath} \mathrm{O}$ 濃度及び温度を パラメータとして一括比較することにした。

Fig. 10 は, 還元速度とスラグ中の $\mathrm{Fe}_{t} \mathrm{O}$ 濃度の関係 について, 比較検討が可能な諸家の実測結果を両対数で 


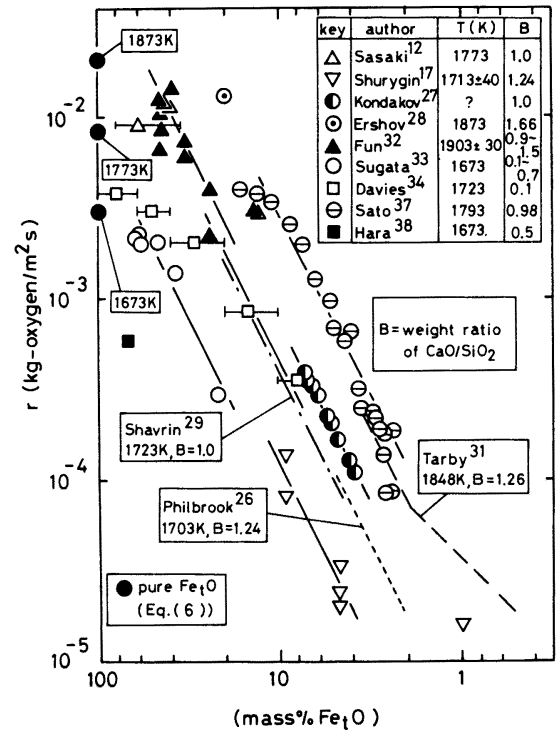

Fig. 10. Relation between the apparent reduction rate of $\mathrm{Fe}_{t} \mathrm{O}$ in liquid $\mathrm{Fe}_{t} \mathrm{O}-\mathrm{CaO}-\mathrm{SiO}_{2}$ slags with solid carbon and mass $\% \mathrm{Fe}_{t} \mathrm{O}$ in the slag. The slags of Shurygin, Kondakov, Fun, Sato, Philbrook, Shavrin and Tarby contain $\mathrm{Al}_{2} \mathrm{O}_{3}$ of $20,10,2,10$, 15,9 and 8.8 mass\%, respectively. The slag of Fun also contains maximum 18.3 mass\% of $\mathrm{MgO}$.

示したものである．測定者間で実験条件がかなり異なる こともあり，還元速度そのものには大きな相違がある. しかし，いずれも還元速度は $\mathrm{Fe}_{t} \mathrm{O}$ 濃度の減少と共に低 下する傾向が認められる. Fig. 10 中の各直線の勾配は, スラグ中の $\mathrm{Fe}_{t} \mathrm{O}$ 濃度に関する反応次数を表わす. $\mathrm{Fe}_{t} \mathrm{O}$ 濃度が 60 から 40 mass\% と比較的高い領域では, Davies $5^{34)}$, 佐々木ら ${ }^{12)}$ が示しているように, 還元速 度の $\mathrm{Fe}_{t} \mathrm{O}$ 濃度依存性はあまり顕著ではない。しかし Davies らは, スラグ中の $\mathrm{Fe}_{t} \mathrm{O}$ 濃度が低下するにつれ て, 反応次数は 0 次から 1 次を経て 2 次へと変化するこ とを認めている. Philbrook $5^{26)}$, Kondakov $5^{27)}$, Shabrin $5^{29)}$, Shurygin $5^{17)}$, 佐藤 ${ }^{37)}$ も $\mathrm{Fe}_{t} \mathrm{O}$ 濃度 が 20 から 2 mass\% の濃度領域では, 還元速度は $\mathrm{Fe}_{t} \mathrm{O}$ 濃度の 2 次に比例すると報告している.これらに対し Krainer $ら^{30)}$ は, 塩基度約 1 の $\mathrm{Fe}_{t} \mathrm{O}-\mathrm{SiO}_{2}-\mathrm{CaO}$ 系スラ グを黒鉛で還元した結果，還元速度は $\mathrm{Fe}_{t} \mathrm{O}$ 濃度の 1 次 に比例すると述べている，一方， $\mathrm{Fe}_{t} \mathrm{O}$ 濃度が 2 mass\% 以下の低濃度領域になると, 反応次数は再び 1 次へ推移 する事が Tarby ら ${ }^{31)} に よ り$ 見出されている.

以上のように，還元の進行による $\mathrm{Fe}_{t} \mathrm{O}$ 濃度の減少に 伴って, 還元速度の $\mathrm{Fe}_{t} \mathrm{O}$ 濃度に関する反応次数は, $0 \rightarrow 1 \rightarrow 2 \rightarrow 1$ 次と変化するようである.この理由は, 一 般的には CO ガスの発生に伴うスラグの泡立ちによる 系の摫拌状態と界面積の変化が密接に関係していると考
えられているが, あくまで定性的な説明に留まっており， 真の理由を明らかにする事は現状では困難である.

反応機構に関する解釈についても, 一致した見解は得 られておらず,いずれも定性的な議論にとどまっている.

Kondakov ら, Shabrin ら, Shurygin ら, Turby ら及 び Fun ${ }^{32)}$ は，スラグ内における何らかの物質移動もし くは拡散過程が律速すると結論している．また Ershov らも, 20 mass\% 以下の $\mathrm{Fe}_{t} \mathrm{O}$ 濃度の時は, 還元速度が スラグ中に浸漬した黒鉛棒の回転数の影響を受ける事か ら，スラグ中の酸素の拡散が律速すると述べている。 こ れらに対し, 須賀田らは還元速度がスラグ中の $\mathrm{Fe}_{t} \mathrm{O}$ の 活量で整理できることから, $\mathrm{Fe}_{t} \mathrm{O}$ と黒鉛の直接還元反 応（( 1 )式)が律速であると主張し, 佐々木らは後に(24) 式で示す $\mathrm{CO}_{2}$ による黒鉛の酸化反応が律速であると述 ベている.

\section{（ 2 )還元速度の塩基度依存性}

Fig. 10 を概観すると，スラグ中の $\mathrm{Fe}_{t} \mathrm{O}$ 濃度が 60 から 5 mass\%の範囲では, いずれの研究結果も還元速 度と $\mathrm{Fe}_{t} \mathrm{O}$ 濃度の間にほぼ 2 次の比例関係が認められ る. そこで, 大略 (17)式の関係が成立している実験值よ り見掛けの 2 次反応速度定数 $k^{2 n d}\left(\mathrm{~kg}-\right.$ oxygen $/ \mathrm{m}^{2} \mathrm{~s}$ $\left.\left(\operatorname{mass} \% \mathrm{Fe}_{t} \mathrm{O}\right)^{2}\right)$ を求め, $k^{2 n d}$ のスラグ塩基度依存性 について検討した.

$$
r=k^{2 n d}\left(\operatorname{mass}_{0} \mathrm{Fe}_{t} \mathrm{O}\right)^{2}
$$

Fig. 11 は, $k^{2 n d}$ とスラグ塩基度との関係を比較して 示したものである. なお, Ershov ら ${ }^{28)} の$ 結果からは $\mathrm{Fe}_{t} \mathrm{O}$ 濃度に対する反応次数を確認することはできない が,ここでは(17)式の関係が成立すると仮定して，他者

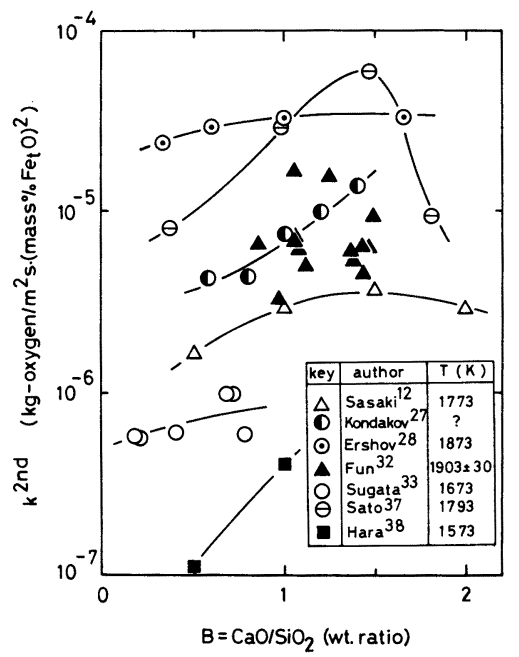

Fig. 11. Effect of the basicity $\mathrm{B}$ on the apparent reduction rate of $\mathrm{Fe}_{t} \mathrm{O}$ in liquid $\mathrm{Fe}_{t} \mathrm{O}-\mathrm{CaO}-\mathrm{SiO}_{2}$ slags with solid carbon. $\mathrm{Al}_{2} \mathrm{O}_{3}$ and $\mathrm{MgO}$ contents in the slags are the same as in Fig. 10. 
の結果との比較検討を行なった.

Fig. 11 より, ばらつきの大きな Fun ${ }^{32)}$ の結果を除け ば，いずれも $k^{2 n d}$ は塩基度の増加と共に大きくなる傾 向が認められる。しかし，佐々木ら ${ }^{12)}$, 佐藤ら ${ }^{37)} に よ$ れば， $k^{2 n d}$ は塩基度 1.5 以上では逆に塩基度の増加と 共に減少し, 結果的に $k^{2 n d}$ は塩基度 1.5 付近で極大值 を示す．佐藤らは, 塩基度が 2 以下の時には $\mathrm{Fe}_{t} \mathrm{O}$ の活 量は塩基度と共に増加する ${ }^{39)}$ 一方，スラグの粘度は塩 基度の増加と共に減少するが, 塩基度 1.2 以上では逆 に塩基度の増加と共に粘度は大きくなり ${ }^{40)}$, その結果 $k^{2 n d}$ は塩基度 1.5 付近で最大になると説明している.

( 3 ) 還元速度の温度依存性

スラグ塩基度一定の条件で還元速度の温度依存性を調

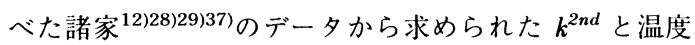
の関係を塩基度をパラメータとして Fig. 12 に示す. 佐 藤らは塩基度の増加と共に温度依存性は小さくなると報 告しているが，佐々木ら，Ershovらの結果では塩基度 による $k^{2 n d}$ の温度依存性の違いは顕著ではない，前述

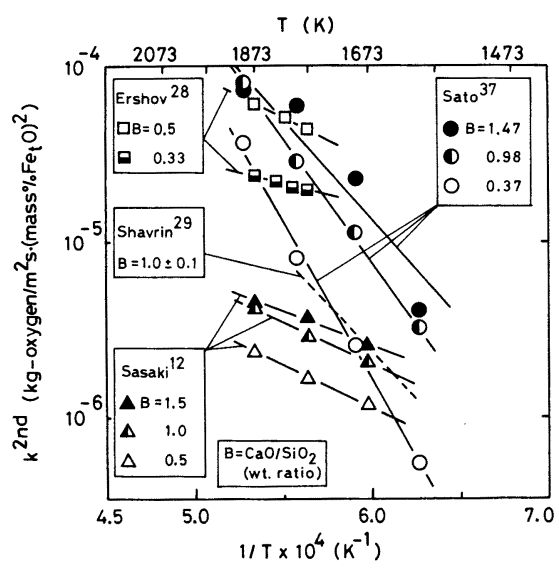

Fig. 12. Temperature dependence of the apparent reduction rate of $\mathrm{Fe}_{t} \mathrm{O}$ in liquid $\mathrm{Fe}_{t} \mathrm{O}-\mathrm{CaO}-\mathrm{SiO}_{2}$ slags with solid carbon. $\mathrm{Al}_{2} \mathrm{O}_{3}$ content in the slags is the same as in Fig. 10.
の Borgianni ${ }^{35)}$ も, 佐々木らと同じ結果を報告している. 見掛けの活性化エネルギー $\Delta E$ は, 佐藤らが純 $\mathrm{Fe}_{t} \mathrm{O}$ の場合に近い 240 から $350 \mathrm{~kJ} / \mathrm{mol}$, Shabrinらが 200 $\mathrm{kJ} / \mathrm{mol}$ を得ているのに対し，佐々木らは $68 \sim 120$ $\mathrm{kJ} / \mathrm{mol}$, Ershov らは 60〜 $120 \mathrm{~kJ} / \mathrm{mol}$ の小さな值を報 告している. なお, Fig. 12 中には示していないが, Krainer $ら^{30)}$ と Borgianni は, 約 $130 \mathrm{~kJ} / \mathrm{mol} の \Delta E$ を 得ている.このように, 測定者によって結果はかなり相 違している.

\section{$5 \cdot 2$ 溶融 $\mathrm{Fe}-\mathrm{C}$ 合金による還元（液液系）}

$5 \cdot 2 \cdot 1$ 還元速度の $\mathrm{Fe}_{t} \mathrm{O}$ 濃度依存性

溶融スラグ中の $\mathrm{Fe}_{t} \mathrm{O}$ の溶融 $\mathrm{Fe}-\mathrm{C}$ 今金による還元 速度は，前述したように，実用上最も重要な知見の一つ と考えられるが, 本系に関する研究は, わずか 6

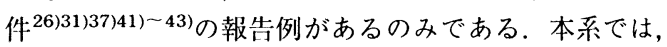
系統的に還元速度のスラグ組成依存性を調べた研究は見 当たらず,その全てが $\mathrm{CaO}-\mathrm{SiO}_{2}-\mathrm{Al}_{2} \mathrm{O}_{3}-(\mathrm{MgO})-\left(\mathrm{Fe}_{t} \mathrm{O}\right)$ 系を研究対象としている. 諸家の実験条件を Table 5 に示す.

Fig. 13 は, 還元速度とスラグ中の $\mathrm{Fe}_{t} \mathrm{O}$ 濃度の関係 を示したものである．還元速度は $\mathrm{Fe}_{t} \mathrm{O}$ 濃度が低下する に伴って減少し, $\mathrm{Fe}_{t} \mathrm{O}$ 濃度が的 20 から 5 mass\%の濃 度領域では 2 次, それ以下の $\mathrm{Fe}_{t} \mathrm{O}$ 濃度では 1 次の比例 関係が成立していることがわかる．本系の還元速度の測 定例は極めて少ないが, 先の Fig. 10 と比較するとわか るように, 還元速度の $\mathrm{Fe}_{t} \mathrm{O}$ 濃度依存性は, 固液系も液 液系も本質的には同じであると推測される.

\section{$5 \cdot 2 \cdot 2$ 還元速度の塩基度及び温度依存性}

本系における還元速度の塩基度依存性は, Hacioglu $ら^{43)}$ ，佐藤ら ${ }^{37)}$ が $\mathrm{Fe}_{t} \mathrm{O}-\mathrm{CaO}-\mathrm{SiO}_{2}-\mathrm{Al}_{2} \mathrm{O}_{3}$ 系スラグで 測定しているのみである. Fig. 13 に示したように，佐 藤らは還元速度は $\mathrm{Fe}_{t} \mathrm{O}$ 濃度の 2 次に比例する結果を得 ているので，(17)式を用いて $k^{2 \text { nd }}$ を求め，その塩基度 依存性を Fig. 14 に示した。一方, Hacioglu らの測定し た還元速度は $\mathrm{Fe}_{t} \mathrm{O}$ 濃度の 1 次に比例しているので, (18)式を適用し, 見掛けの 1 次速度定数 $k^{1 s t}(\mathrm{~kg}-$ oxygen $/ \mathrm{m}^{2} \mathrm{~s}\left(\right.$ mass\% $\left.\left.\mathrm{Fe}_{t} \mathrm{O}\right)\right)$ を求めてその塩基度依存性

Table 5. Experimental conditions and the method to determine the rate of reduction of $\mathrm{Fe}_{t} \mathrm{O}$ in liquid slags with $\mathrm{Fe}-\mathrm{C}$ melts.

\begin{tabular}{|c|c|c|c|c|c|c|c|c|c|c|c|}
\hline Author & Ref. & $\begin{array}{c}\text { Temp. } \\
(\mathrm{K})\end{array}$ & Crucible & $\begin{array}{c}\text { Wt. of } \\
\mathrm{Fe}^{-} \mathrm{C}(\mathrm{g})\end{array}$ & [mass $\%$ ] & $\underset{\text { system }}{\text { Slag }_{\#}}$ & $\begin{array}{c}\text { Slag wt. } \\
(\mathrm{g})\end{array}$ & $\begin{array}{c}\mathrm{CaO} / \mathrm{SiO}_{2} \\
(\text { in wt. })\end{array}$ & $\begin{array}{c}\mathrm{Fe}_{1} \mathrm{O} \\
(\mathrm{mass} \%)\end{array}$ & Method $^{*}$ & $\begin{array}{c}\text { Area } A \\
\left(\mathrm{~cm}^{2}\right)\end{array}$ \\
\hline Philbrook & 26 & 1703,1843 & Graphite & 300 & sat. & FCSA & 65,100 & 1.24 & $0.3 \sim 4.9$ & C.A. & 18,36 \\
\hline Tarby & 31 & 1773,1848 & Graphite & 400 & sat. & FCSA & 100 & 1.25 & $?$ & C.A. & 30 \\
\hline $\begin{array}{l}\text { Sommerville } \\
\text { Upadaya }\end{array}$ & $\begin{array}{l}41 \\
42 \\
\end{array}$ & 1653,1673 & $\begin{array}{c}\text { Iron }+ \\
\mathrm{Al}_{2} \mathrm{O}_{3} \\
\end{array}$ & 30 & $2.5 \sim$ sat. & FCSA & 30 & 0.9 & $0.4 \sim 3.2$ & $\Sigma \mathrm{CO}$ & 9.6 \\
\hline Hacioglu & 43 & 1678,1768 & $\mathrm{Al}_{2} \mathrm{O}_{3}$ & $?$ & $2.3 \sim 4.2$ & FCSAM & $?$ & $0.50 \sim 1.16$ & $1-8$ & $\Sigma \mathrm{CO}+\mathrm{C} . \mathrm{A}$. & $?$ \\
\hline Sato & 37 & $1593 \sim 1893$ & $\begin{array}{c}\text { Graphite } \\
\mathrm{Al}_{2} \mathrm{O}_{3}\end{array}$ & 1500 & sat. & FCSA & 40 & $0.37 \sim 1.81$ & $2 \sim 30$ & $\Sigma \mathrm{CO}$ & 23.8 \\
\hline
\end{tabular}

\# : Keys as in Table 4. * : Keys as in Table 1 and Table 3. 


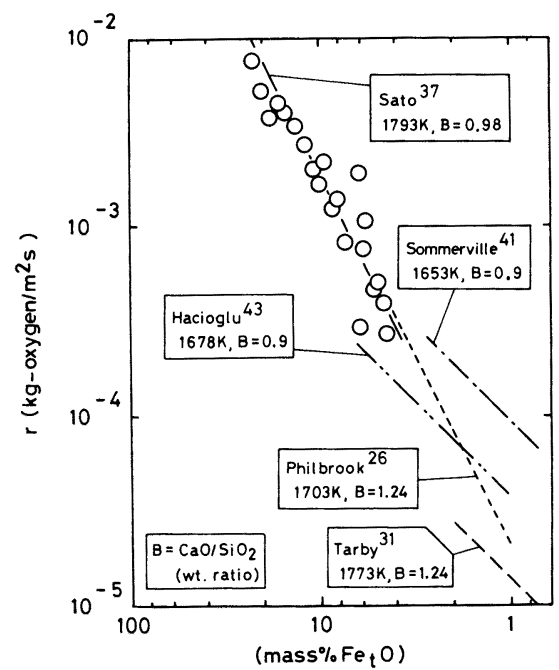

Fig. 13. Relation between the apparent reduction rate of $\mathrm{Fe}_{t} \mathrm{O}$ in liquid $\mathrm{Fe}_{t} \mathrm{O}-\mathrm{CaO}-\mathrm{SiO}_{2}$ slags with $\mathrm{Fe}-\mathrm{C}$ melts and mass $\% \mathrm{Fe}_{t} \mathrm{O}$ in the slag. The slags of Philbrook, Tarby, Sato, Sommerville and Hacioglu contain $\mathrm{Al}_{2} \mathrm{O}_{3}$ of $15,8.8,10,20$ and 20 mass\%, respectively.

を Fig. 14 中に闹時に示した。

$r=k^{1 s t}\left(\operatorname{mass} \% \mathrm{Fe}_{t} \mathrm{O}\right)$

Fig. 14 より, 塩基度 1.5 以下の範囲では, $k^{1 s t}, k^{2 n d}$ のいずれも塩基度の増加と共に大きくなっている事がわ かる. しかし佐藤らによる $k^{2 n d}$ は, 塩基度 1.5 付近で 最大值を示し, 現象としては Fig. 11 に示した固液系の 場合と同じである。また同一塩基度で比較すると， $\mathrm{Al}_{2} \mathrm{O}_{3}$ を 10 mass\% 含むスラグより, $\mathrm{Al}_{2} \mathrm{O}_{3}$ 飽和スラグ の方が $k^{2 n d}$ は低くなっており， $\mathrm{Al}_{2} \mathrm{O}_{3}$ は還元速度を遅 くするといえる.なお, Fig. 14 中には比較のために, Fig. 10 中に示した佐藤らによる $\mathrm{Fe}_{t} \mathrm{O}-\mathrm{CaO}-\mathrm{SiO}_{2}-10$

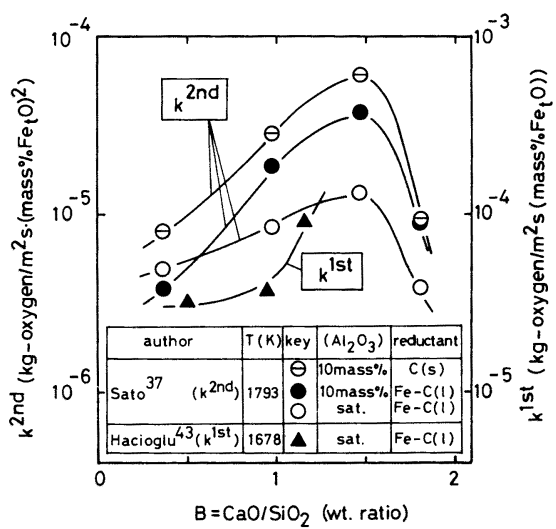

Fig. 14. Effect of the basicity $\mathrm{B}$ on the apparent reduction rate of $\mathrm{Fe}_{t} \mathrm{O}$ in liquid $\mathrm{Fe}_{t} \mathrm{O}-\mathrm{CaO}$ $\mathrm{SiO}_{2}-\mathrm{Al}_{2} \mathrm{O}_{3}$ slags with $\mathrm{Fe}-\mathrm{C}$ melts.

mass\% $\mathrm{Al}_{2} \mathrm{O}_{3}$ スラグの固液系における $k^{2 n d}$ を示したが, 固体炭素による $k^{2 n d}$ の方が炭素飽和溶鉄による $k^{2 n d}$ よ り大きくなっており, Fig. 8 に示した純 $\mathrm{Fe}_{t} \mathrm{O}$ の場合と 逆になっている.

本系における還元速度の温度依存性は, Tarby $5^{31)}$,

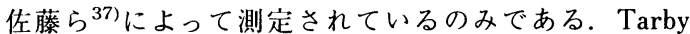
らによる $k^{1 s t}$ と佐藤らによる $k^{2 n d}$ と温度との関係を Fig. 15 に示す. 佐藤らの結果によれば, 先の固液系の 場合とは逆に， $\Delta E$ は塩基度の増加と共に大きくなり, 塩基度 0.5 では $165 \mathrm{~kJ} / \mathrm{mol}$, 塩基度 1.5 では 250 $\mathrm{kJ} / \mathrm{mol}$ が得られている. Tarby らの実験温度範囲は狭 いが, 約 $60 \mathrm{~kJ} / \mathrm{mol}$ の比較的小さな $\Delta E$ が得られてい る.

\section{$5 \cdot 3$ ガスによる還元（気液系）}

本系に関する諸家 ${ }^{44) ~ 50)}$ の実験条件を Table 6 に示 す.

Table 6. Experimental conditions and the method to determine the rate of reduction of $\mathrm{Fe}_{t} \mathrm{O}$ in liquid slags with $\mathrm{H}_{2}$ or $\mathrm{CO}$.

\begin{tabular}{|c|c|c|c|c|c|c|c|c|c|c|c|}
\hline Author & Ref. & Temp. & Crucible & $\underset{\text { system }}{\text { Slag }}$ & $\begin{array}{l}\text { Slag wt. } \\
(\mathrm{g})\end{array}$ & $\begin{array}{c}\mathrm{CaO} / \mathrm{SiO}_{2} \\
\text { (in wt.) }\end{array}$ & $\begin{array}{c}\mathrm{Fe}_{t} \mathrm{O} \\
(\mathrm{mass} \%)\end{array}$ & Reductant & $\begin{array}{c}\text { Gas composition } \\
(\mathrm{atm})\end{array}$ & Method $^{*}$ & $\begin{array}{c}\text { Area } A \\
\left(\mathrm{~cm}^{2}\right)\end{array}$ \\
\hline Katayama & 44 & 1723,1833 & $\mathrm{MgO}$ & FCSAM & 3 & 1.17 & $4.45-13.4$ & $\mathrm{H}_{2}-\mathrm{H}_{2} \mathrm{O}-\mathrm{Ar}$ & $\begin{array}{c}P_{\mathrm{H}_{2}}=0.01 \sim 0.5 \\
\mathrm{H}_{2} \mathrm{O} / \mathrm{H}_{2}<0.0029\end{array}$ & $\Delta \mathrm{WS}$ & 2.56 \\
\hline Hayashi & 45 & $1273 \sim 1573$ & Iron & $\mathrm{Fe}^{-} \mathrm{O}-\mathrm{S}$ & 1 & & $35 \sim 70$ & $\mathrm{H}_{2}-\mathrm{N}_{2}$ & $P_{\mathrm{H}_{2}}=0.02 \sim 0.3$ & $\Delta \mathrm{WS}$ & 2.42 \\
\hline Fine & 46 & 1833,1873 & $\mathrm{MgO}$ & FCSM & $1.5 \sim 2$ & 1.15 & 67.7 & $\mathrm{CO}$ & $P_{\mathrm{CO}}=1$ & G.A. & $17.7 \sim 24.9$ \\
\hline Nagasaka & $\begin{array}{l}47 \\
48\end{array}$ & $1593-1723$ & Iron & $\begin{array}{l}\mathrm{FS}, \mathrm{FC} \\
\text { FCS }^{\$}\end{array}$ & 3.5 & $0.23 \sim 1.87$ & $33 \sim 96$ & $\mathrm{CO}-\mathrm{CO}_{2}-\mathrm{Ar}$ & $\begin{array}{c}P_{\mathrm{CO}}=0.003 \sim 0.5 \\
\mathrm{CO}_{2} / \mathrm{CO}=0 \sim 0.24\end{array}$ & $\Delta \mathrm{WS}$ & 2.45 \\
\hline Kim & 49 & 1833,1873 & $\mathrm{MgO}$ & FCSM & $1.5 \sim 2$ & $0.34 \sim 1.12$ & $5 \sim 90$ & $\begin{array}{c}\mathrm{CO}-\mathrm{CO}_{2}^{-} \\
\mathrm{Ar}-\mathrm{SO}_{2} \\
\end{array}$ & $\begin{array}{c}P_{\mathrm{CO}}=0.006 \sim 1 \\
\mathrm{CO}_{2} / \mathrm{CO}=0.03 \sim 0.2\end{array}$ & G.A. & $17.7 \sim 24.9$ \\
\hline Sasabe & 50 & 1623,1723 & Iron & FCSP & 10 & $0.5,1.0$ & 20,60 & $\mathrm{CO}$ & $P_{\mathrm{CO}}=1$ & $\Delta \mathrm{WS}$ & $?$ \\
\hline
\end{tabular}

\# : Keys as in Table 4. *: Keys as in Table 3.

$\$$ : Other slag systems investigated were $\mathrm{Fe}_{t} \mathrm{O}-\mathrm{M}_{x} \mathrm{O}_{y}(\mathrm{M}: \mathrm{Na}, \mathrm{Mg}, \mathrm{Mn}, \mathrm{Al}, \mathrm{Ti}, \mathrm{P})$ and $\mathrm{Fe}_{t} \mathrm{O}-\mathrm{FeS}$ binaries, $\mathrm{Fe}_{t} \mathrm{O}-\mathrm{SiO}_{2}-\mathrm{M}_{x} \mathrm{O}_{y}(\mathrm{M}: \mathrm{Na}, \mathrm{Mg}, \mathrm{Mn})$, $\mathrm{Fe}_{\imath} \mathrm{O}-\mathrm{CaO}-\mathrm{CaX}{ }_{y}(\mathrm{X}: \mathrm{Cl}, \mathrm{F})$ ternaries and $\mathrm{Fe}_{t} \mathrm{O}-\mathrm{CaO}-\mathrm{SiO}_{2}-\mathrm{P}_{2} \mathrm{O}_{5}$ quaternary. 


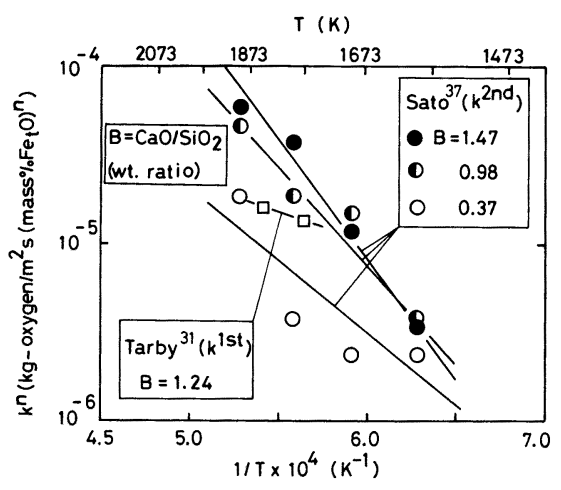

Fig. 15. Temperature dependence of the apparent reduction rate of $\mathrm{Fe}_{t} \mathrm{O}$ in liquid $\mathrm{Fe}_{t} \mathrm{O}-\mathrm{CaO}^{-}$ $\mathrm{SiO}_{2}-\mathrm{Al}_{2} \mathrm{O}_{3}$ slags with $\mathrm{Fe}-\mathrm{C}$ melts. $\mathrm{Al}_{2} \mathrm{O}_{3}$ contents in the slags are the same as in Fig. 13.

\section{$5 \cdot 3 \cdot 1 \quad \mathrm{H}_{2}$ による還元}

溶融スラグ中 $\mathrm{Fe}_{t} \mathrm{O}$ の $\mathrm{H}_{2}$ による還元速度は, 片山 $ら^{44)}$ ，林ら ${ }^{45)}$ が測定している．林らは硫黄を $20 \mathrm{~mol} \%$ 以上含む $\mathrm{Fe}-\mathrm{S}-\mathrm{O}$ 系融体を対象としており， $\mathrm{H}_{2}$ による 脱硫反応が同時に進行するため現象としてはかなり複雑 である. 一方, 片山らは $\mathrm{MgO}$ 飽和 $\mathrm{CaO}-\mathrm{SiO}_{2}-\mathrm{Al}_{2} \mathrm{O}_{3}$ スラグ中 4.5 mass\% 以下の $\mathrm{Fe}_{t} \mathrm{O}$ の還元速度を測定し ており, 反応初期では化学反応律速であるとし，1723 $\mathrm{K}$ で次の速度式を得ている.

$$
r=1.45 \times 10^{-5} P_{\mathrm{H}_{2}}{ }^{1 / 2}\left(N_{\mathrm{Fe}_{t} \mathrm{O}}-0.72 P_{\mathrm{H}_{2} \mathrm{O}} / P_{\mathrm{H}_{2}}\right)
$$

ここで， $N_{\mathrm{Fe}_{t} \mathrm{O}}$ はスラグ中の $\mathrm{Fe}_{t} \mathrm{O}$ のモル分率である.

本系では片山らの結果と比較できる報告例は見当たら ないが, 最近 Glaws ら ${ }^{51)}$ は重水を用いた同位体交換法 を用いて, $\mathrm{SiO}_{2}$ 飽和の溶融 $\mathrm{Fe}_{t} \mathrm{O}$ と $\mathrm{H}_{2}-\mathrm{H}_{2} \mathrm{O}$ ガス間の 反応速度の測定を試みており，今後注目される研究の一 つである。

$5 \cdot 3 \cdot 2$ CO による還元

本系に関しては， 5 件の報告例 ${ }^{46)}$-50)があるのみであ る.このうち, Fine ら ${ }^{46)}, \mathrm{Kim} ら^{49)}$ は, $\mathrm{MgO}$ 飽和 $\mathrm{Fe}_{t} \mathrm{O}-\mathrm{CaO}-\mathrm{SiO}_{2}-\mathrm{MgO} 4$ 元系スラグのみを研究対象に している。また, 雀部ら ${ }^{50)} も \mathrm{Fe}_{t} \mathrm{O}-\mathrm{CaO}-\mathrm{SiO}_{2}-\mathrm{P}_{2} \mathrm{O}_{5}$ 4 元系スラグで実験しているが, 反応界面積が不明であ る.これらに対して長坂ら ${ }^{47) 48)}$ は，多くのスラグ系及 び広いスラグ, ガス組成範囲で還元速度を測定している. なお, Fine ら, Kim ら, 長坂らの結果は, いずれも還 元が化学反応によって律速される条件での值である.

Fig. 16 は，長坂ら ${ }^{47) 48)} に よ り$ 測定された $\mathrm{Fe}_{t} \mathrm{O}-\mathrm{M}_{x} \mathrm{O}_{y}$ 2 元系スラグの CO による還元速度と, スラグ中の $\mathrm{Fe}_{t} \mathrm{O}$ 濃度の関係を示したものである. Fig. 16 より, 還元速度は酸性酸化物濃度の増加と共に減少し，塩基性 酸化物の添加によって逆に増加していることがわかる。

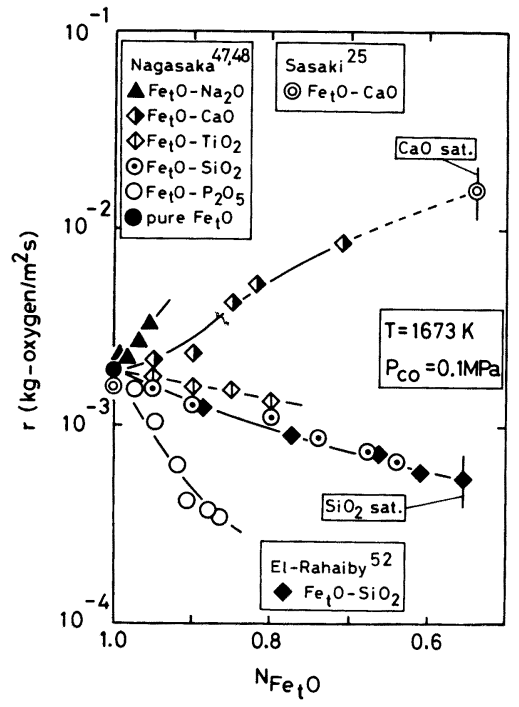

Fig. 16. Effect of additive oxides on the rate of reduction of liquid $\mathrm{Fe}_{t} \mathrm{O}$ with $\mathrm{CO}$ at $1673 \mathrm{~K}$ and $P_{\mathrm{CO}}=0.1 \mathrm{MPa}$.

Sasaki $5^{25)}$ ，El-Rahaiby $5^{52)}$ は，同位体交換法を用 い, $\mathrm{Fe}_{t} \mathrm{O}$ を含む多元系スラグ中の $\mathrm{Fe}_{t} \mathrm{O}$ の $\mathrm{CO}-\mathrm{CO}_{2}$ による酸化速度を測定している.これらは還元速度の直 接測定例ではないが，先に詳述したように，彼らの結 果をCOによる還元速度に換算し，比較検討する事 が可能である．彼らの結果から計算した $\mathrm{Fe}_{t} \mathrm{O}-\mathrm{CaO}$, $\mathrm{Fe}_{t} \mathrm{O}-\mathrm{SiO}_{2}$ 系における還元速度を比較のために Fig. 16 中に示す. $\mathrm{Fe}_{t} \mathrm{O}-\mathrm{SiO}_{2}$ 系における長坂らと El-Rahaiby らの結果は極めてよく一致している．また， $\mathrm{Fe}_{t} \mathrm{O}-\mathrm{CaO}$ 系における Sasaki ら ${ }^{25)}$ の結果は長坂らの結果の延長線

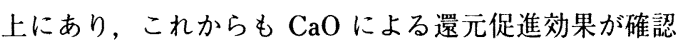
される.

Fig. 17 は, 長坂らによって測定された $\mathrm{Fe}_{t} \mathrm{O}$ $\mathrm{SiO}_{2}-\mathrm{CaO}$ 系における $\mathrm{CO}$ 還元速度の塩基度依存性を 示したものである，還元速度は塩基度の上昇とともに増 加することがわかる. 彼らは, $\mathrm{Fe}_{t} \mathrm{O}-\mathrm{SiO}_{2}$ 系に $\mathrm{Na}_{2} \mathrm{O}$, $\mathrm{MnO}, \mathrm{MgO}$ を添加した 3 元系スラグについても同様の 傾向を見出している。 El-Rahaiby らも， $\mathrm{Fe}_{t} \mathrm{O}-\mathrm{CaO}-$ $\mathrm{SiO}_{2}$ スラグの $\mathrm{CO}_{2}$ による酸化速度は, 塩基度に比例 して増加する事を報告している. また Fig. 17 において， 塩基度が約 1 の場合，還元速度は $\mathrm{Fe}_{t} \mathrm{O}$ 濃度にあまり依 存せず，ほぼ一定值を示している事が特徴的である.

El-Rahaiby $ら^{52)}$ も, 塩基度 $1, \mathrm{Fe}_{t} \mathrm{O}$ 濃度が 80 から 5 $\mathrm{mol} \%$ の条件では，スラグ中 $\mathrm{Fe}_{t} \mathrm{O}$ の $\mathrm{CO}_{2}$ による酸化 速度は純 $\mathrm{Fe}_{t} \mathrm{O}$ の場合と同じであったと報告しており,

Fig. 20 に示した気液系の傾问を裏付けている.

このように，還元速度がスラグの塩基度に強く依存す る現象は，スラグ中の $\mathrm{Fe}_{t} \mathrm{O}$ の濃度や活量の変化では説 


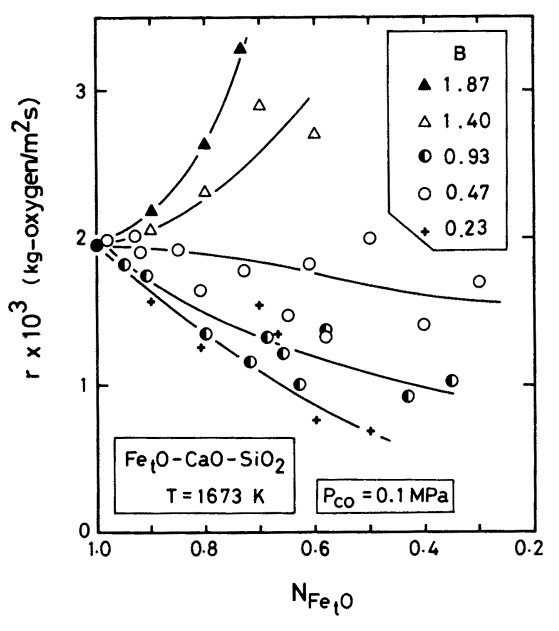

Fig. 17. Relation between the rate of reduction of $\mathrm{Fe}_{t} \mathrm{O}$ in $\mathrm{Fe}_{t} \mathrm{O}-\mathrm{CaO}-\mathrm{SiO}_{2}$ slags with $\mathrm{CO}$ and $\mathrm{Fe}_{t} \mathrm{O}$ content as the function of the basicity $\mathrm{B}=$ $($ mass $\% \mathrm{CaO}) /\left(\operatorname{mass} \% \mathrm{SiO}_{2}\right)$ at $1673 \mathrm{~K}$ and $P_{\mathrm{CO}}=$ $0.1 \mathrm{MPa}$ (after Nagasaka et al. $^{47) 48)}$ ).

明できない，長坂らは，スラグ中の $\mathrm{Fe}^{3+} / \mathrm{Fe}^{2+}$ 比が系 の塩基度に対応して変化することに着目し, 種々のスラ グにおける還元速度をスラグ中の $\mathrm{Fe}^{3+}$ と $\mathrm{Fe}^{2+}$ の存 在比で整理した. その結果 Fig. 18 に示すように，還元 速度とスラグ中の $\mathrm{Fe}^{3+}$ と $\mathrm{Fe}^{2+}$ の存在比は, よい対 応関係を示しており, 唯一例外的であった $\mathrm{P}_{2} \mathrm{O}_{5}$ を含む 系を除いたすべてのスラグ系での実験結果より, 長坂ら は次の様な経験的速度式を提案している.

$$
r=k_{r}^{\prime}\left(N_{\mathrm{FeO}_{1.5}}^{2} / N_{\mathrm{FeO}}^{3}\right)^{1 / 3}\left(P_{\mathrm{CO}}-P_{\mathrm{CO}_{2}} / K_{\mathrm{C}}^{\prime}\right)
$$

なお $\mathrm{P}_{2} \mathrm{O}_{5}$ は強い表面活性物質として作用するため $(20)$
式は $\mathrm{P}_{2} \mathrm{O}_{5}$ を含むスラグには適用できないとしている. 諸家の測定結果を(20)式を用いて再整理して得た $k_{r}$ と温度の関係を Fig. 19 に示す.諸家の実験結果はほぼ (21)式で表現されている.

$$
k_{r}^{\prime}=\exp (-16600 / T-6.37)\left(\mathrm{kg} \text {-oxygen } / \mathrm{m}^{2} \mathbf{s} \cdot \mathrm{Pa}\right)
$$

$\Delta E$ は, スラグの塩基度によっても多少異なるが, 約 $140 \mathrm{~kJ} / \mathrm{mol}$ の值が得られている.ただし, 現状では(20) 式中の $\mathrm{Fe}^{3+} / \mathrm{Fe}^{2+}$ 比がもつ物理化学的意味は不明であ るが，スラグ表面でのイオン間の電子の授受反応が何ら かの役割を演じているのではないかと推測してい $ろ^{47) 48)}$.

同位体交換法を用いた Belton一派の研究 ${ }^{25) 52) 53) て ゙ ~}$ も，スラグ中 $\mathrm{Fe}_{t} \mathrm{O}$ の $\mathrm{CO}_{2}$ による酸化速度は, $\mathrm{Fe}^{3+}$ $/ \mathrm{Fe}^{2+}$ 比に比例する現象を認めている。 この事実を基 に彼らは, $\mathrm{CO}_{2}{ }^{2-}$ イオン等が反応に関与する可与能性を 示している. 一方 $\operatorname{Kim} 5^{49)}$ は, 塩基度 1.12 以下の場合, 還元速度のスラグ組成依存性が $\mathrm{SiO}_{2}$ の活量を用いて整 理できる事を示し, $\mathrm{SiO}_{2}$ の表面吸着が影響することを 示唆している.

以上の様に, 溶融 $\mathrm{Fe}_{t} \mathrm{O}$ の $\mathrm{CO}$ による還元速度は, 比較的精度の高い測定が可能であり，還元速度の組成依 存性もかなり明らかにされている.反応機構については, 前述の固液, 液液系に比べて, かなり踏み込んだ議論が なされるようになってきた．測定例はいまだ少なく，化 学反応機構も十分解明されているとはいえないが, 全体 像はかなり明確にされつつあり, $\mathrm{Fe}_{t} \mathrm{O}$ の溶融還元機構 を解明する上で有益な情報になると考えられる.

ところで, 固液, 液液系における $\mathrm{Fe}_{t} \mathrm{O}$ の還元機構に ついては, これまで様々なモデルが提案されているが,

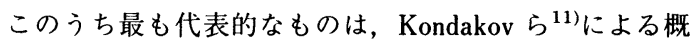
念である.すなわち，溶融 $\mathrm{Fe}_{t} \mathrm{O}$ 相と黒鉛または溶融

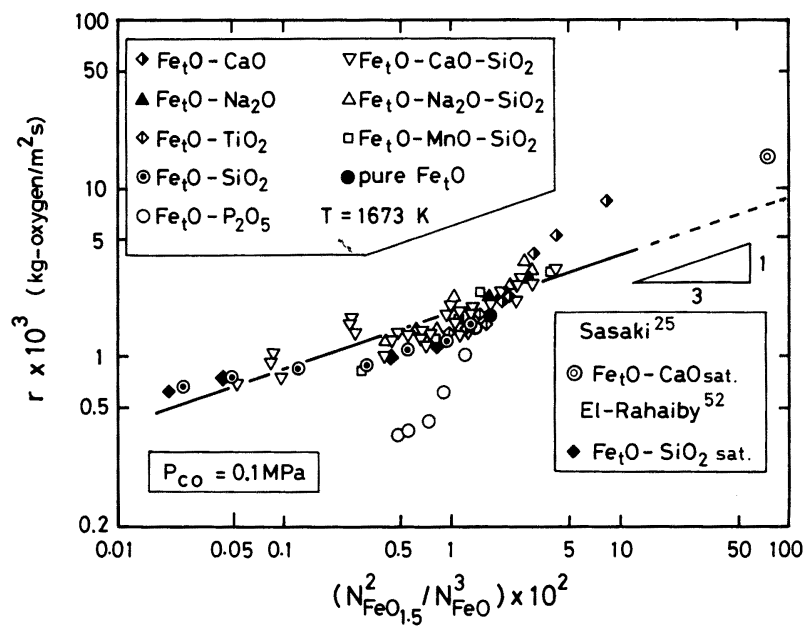

Fig. 18. Relation between the rate of reduction of $\mathrm{Fe}_{t} \mathrm{O}$ in liquid slags with $\mathrm{CO}$ and ferrous-ferric ratio in the slag at $1673 \mathrm{~K}$ and $P_{\mathrm{CO}}=0.1 \mathrm{MPa}$ (after Nagasaka et al. ${ }^{47) 48)}$ ). 


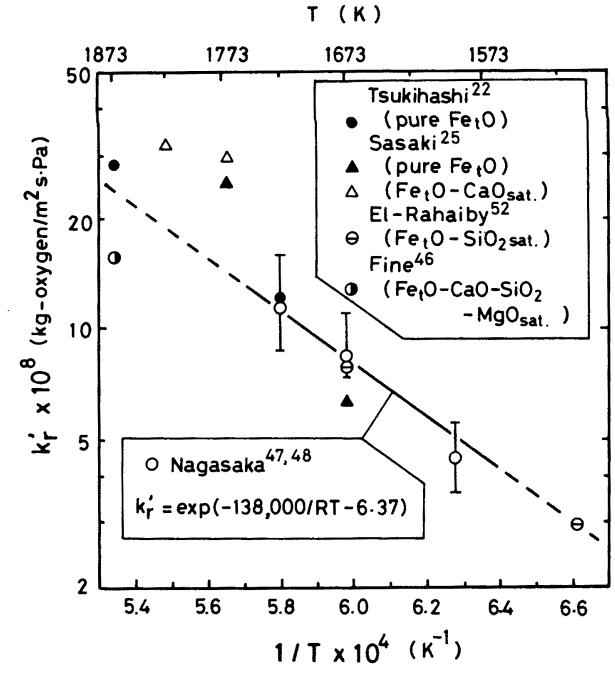

Fig. 19. Temperature dependence of the apparent reduction rate constant $k_{r}^{\prime}$ defined by Eq. (20) (after Nagasaka et al. ${ }^{47) 48)}$ ).

$\mathrm{Fe}-\mathrm{C}$ 相は，還元反応によって生成したガス相により隔 離され，総括還元反応である(22)式は，見掛け上(23)式 と(24)式の組合せで進行するというものである.

$\mathrm{Fe}_{t} \mathrm{O}(\mathrm{l})+\mathrm{C}(\mathrm{s})$ or $\underline{\mathrm{C}}=t \mathrm{Fe}(\mathrm{l}$ or $\mathrm{s})+\mathrm{CO}_{2}(\mathrm{~g})$

$\mathrm{Fe}_{t} \mathrm{O}(\mathrm{l})+\mathrm{CO}(\mathrm{g})=t \mathrm{Fe}(\mathrm{l}$ or s $)+\mathrm{CO}_{2}(\mathrm{~g})$

$\mathrm{C}(\mathrm{s})$ or $\underline{\mathrm{C}}+\mathrm{CO}_{2}(\mathrm{~g})=2 \mathrm{CO}(\mathrm{g})$

このモデルは, 固液, 液液系における $\mathrm{Fe}_{t} \mathrm{O}$ の還元速度

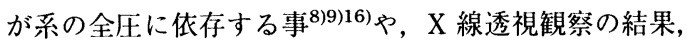

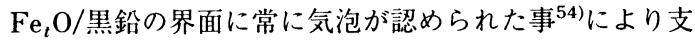
持されている. 実際には(22)式の反応も絶えず起こって いるが, その寄与は小さいと考えられている.

その後多くの研究者がこのモデルに基づいて還元機構 を考察し，1.(23)式の反応は速く, 平衡状態にあると予 想される事 ${ }^{55)}, 2$. 総括還元速度の $\Delta E$ が，(24)式の反 応のそれに近い事，3.系はガス発生によって強い攪汼状 態にあるため, 物質移動の影響は無視できると予想され る事等から，結局(24)式の反応が律速段階である可能性 を指摘している ${ }^{9)-13) 36) 55) . ~ し か し な か ゙ ら, ~ F i g . ~ 10, ~ 13 ， ~}$ 16, 17 よりわかるように, $\mathrm{Fe}_{t} \mathrm{O}-\mathrm{CaO} 2$ 元系を除けば, 気液系の還元速度は約 $10 \mathrm{mass} \%$ 以上では固液, 液液系 の場合より遅く，少なくとも(23)式の寄与が無視できる とはいえないようである ${ }^{30) 41) 42)}$. 実際に佐藤ら ${ }^{14)}$ は, 炭素飽和溶鉄によるスラグ中からの $\mathrm{Fe}_{t} \mathrm{O}$ の還元速度が スラグ相厚さに依存する事から，スラグ相を浮上する CO 気泡による $(23)$ 式の反応が無視できないことを指摘 している.

最近柴田ら ${ }^{56)}$ は，上記の概念に従って(23)式と (24)
式の既報の反応速度 ${ }^{4957)}$ を用い，スラグ中の $\mathrm{Fe}_{t} \mathrm{O}$ と 炭素飽和溶鉄間の反応機構を考察している. 彼らは， ス ラグーメタル界面の気泡に作用する静的な力のバランス から気泡の形状と占有率を計算し, かなり厳密な解析を 行なっているが, モデルによる計算值は固液, 液液系に おける諸家の還元速度より低く, 実測值を再現できな かった．徳田 ${ }^{6)}$ も同様の考察を行ない, 全体としては還 元速度を定性的に表現できるが，(23)，(24)式のいずれ が支配的になるかは特定できないとしている，なお，柴 田ら, 徳田は, その他興味深い指摘を行なっているので, 詳細は彼らの論文を参照されたい.

\section{6.お わりに}

これまで紹介してきた溶融 $\mathrm{Fe}_{t} \mathrm{O}$ の還元速度の研究例 の中で, 複数の研究者により確認されている共通解を探 してみると以下の 4 点が挙げられよう。 1.溶融純 $\mathrm{Fe}_{t} \mathrm{O}$ の還元速度は, 溶融 $\mathrm{Fe}-\mathrm{C}$ 合金による液液系が最も速 く, 次いで黒鉛による固液系, $\mathrm{CO}$ による気液系である. 2. $\mathrm{Fe}_{t} \mathrm{O}$ への $\mathrm{SiO}_{2}$ の添加は, 還元速度を低下させる. 3. スラグ中の $\mathrm{Fe}_{t} \mathrm{O}$ の還元速度は, 塩基度 0.5 から 1.5 の範囲内では, スラグの塩基度の増加と共に大きくなる. 4. 固体炭素によるスラグ中の $\mathrm{Fe}_{t} \mathrm{O}$ の還元速度は, 60 から 5 mass\% $\mathrm{Fe}_{t} \mathrm{O}$ の組成範囲ではスラグ中の $\mathrm{Fe}_{t} \mathrm{O}$ 濃 度の 2 次に比例する。逆説的に言うと，まだこの程度の 知見しか得られていないといっても過言ではない状態で ある.これはひとえに研究例の貧困さが最大の原因であ るが, 溶融 $\mathrm{Fe}_{t} \mathrm{O}$ の還元が, 実験的に反応機構を解明す る事がいかに困難な現象であるかを象徵しているように 思える．また，最近報告されている鉄浴式溶融還元製鉄 法における試験操業条件 ${ }^{1)}$ に近い実験条件，すなわち塩 基度 1 から 1.2 の高炉タイプスラグ $\left(\mathrm{CaO}-\mathrm{SiO}_{2}-\mathrm{Al}_{2} \mathrm{O}_{3}\right.$ 系) 中約 5 mass\% $\% \mathrm{Fe}_{t} \mathrm{O}$ の溶融 $\mathrm{Fe}-\mathrm{C}$ 合金 $(4 \sim 5$ mass\% C) による還元速度を, $1673 \mathrm{~K}$ から $1773 \mathrm{~K}$ の 温度範囲で測定した例は，わずか 6 例 ${ }^{26) 31) 37) 41) ~ 43) ~ し か ~}$ ない，近い将来溶融還元法を完成させるためには，今回 紹介したような基礎実験データが不可欠なものになると 考えられ，今後の研究を期待したい.

緒言でも述べたように，溶融 $\mathrm{Fe}_{t} \mathrm{O}$ の還元反心は非常 に複雑な現象を伴うため, 単純にるつほ内で溶融 $\mathrm{Fe}_{t} \mathrm{O}$ と還元剤を反応させるような実験手法だけでは真の反応 機構を解明する事は困難であると思われる，従って，溶 融還元反応に付随する融体中の気泡の挙動やスラグの泡 立ち現象等を正しく把握し, 反忍工学的知見と組合せて 全体を理解する事が重要であろう。なおスラグの泡立ち

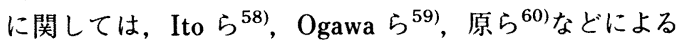
優れた報告がある。また, 1989 年の Steel Research 第 $3 ， 4$ 巻は，溶融還元法に関する米-独セミナーの特集

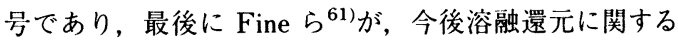
基礎研究が進むべき方向をコメントしているので参照さ 
れたい。

本稿は, 日本学術振與会製銑第 54 委員会還元反心検 討 WGへの提出資料を基にしたものである. 貴重な御 意見，御批判を頂いた小野陽一九州大学教授を始めとす るWG 委員各位, 及び有益な御助言を賜わった不破祐 東北大学名誉教授, 館充千葉】業大学教授に感謝致しま す.

\section{文献}

1) 例之ば, 松毛旮高, 斎藤 力, 片山裕之, 平田 浩, 金本通隆, 茨城哲治: 鉄と鋼, 76 (1990), p. 1871

2 ) 例えば, C. Yamagata, K. Kajiwara, S. Suyama and T. Miyake: ISIJ Int., 30 (1990), p. 740

3 ) 森 一美: 学振第 54 委-No. 1072 (昭和 42 年 4 月)

4 ) 中村正利, 徳光沽樹: 鉄と龬, 67 (1981),p. 480

5 ) 相馬胤和: H本金属学会会報, 21 (1982), p. 620

6 ) 徳田昌則: 第 $116 \cdot 117$ 回西山記念技術講座 (日本鉄鋼協会 編) (1987), p. 199

7 ）不破 祼: H本金属学会会報, 26 (1987), p. 365

8 ) D. I. Ryzenkov, D. M. Golenko and L. M. Chelyadunov: Izv. VUZ Chern. Met. (1960) 4, p. 19

9 ) V. V. Kondakov, D. I. Ryzenkov and D. M. Golenko: Izv. VUZ Chern. Met. (1960) 4, p. 23

10）加藤栄一, 桜谷和之, 山縣千里: 早大鋳研報告, 28 (1973), p. 67

11）高橋萧治, 天庯正義, 相馬片和: 鉄と鋼, 61 (1975), p. 2525

12）佐々木康, 相馬扸和: 鉄と鋼, 64 (1978), p. 376

13）月橋文孝, 天辰正義, 相馬㻆和: 鉄と鋼, 68 (1982), p. 1880

14）佐藤 彰, 荒金吾郎, 上平一茂, 吉松史郎: 鉄と鋼, 73 (1987), p. 812

15) T. E. Dancy: J. Iron Steel Inst., 169 (1951), p. 17

16) D. R. MacRae: J. Met., 17 (1965), p. 1391

17) P. M. Shurygin, V. N. Boronenkov, V. I. Kriuk and V. V. Revebtsov: Izv. VUZ. Chern. Met. (1965) 2, p. 23

18) G. W. Lloyd, D. R. Young and L. A. Baker: Ironmaking Steelmaking, 2 (1975), p. 49

19）佐藤 彰, 中川龍一, 古松史郎, 福沢 章, 尾崎 太: 鉄と鋼, 67 (1981), p. 303

20 ）萬谷志郎, 井儿秦孝, 長坂徹也: 鉄と鋼, 70 (1984), p. 1689

21) K. Kato, Y. Sasaki and T. Soma: Trans. Iron Steel Inst. Jpn., 17 (1977), p. 532

22）月橋文考, 加藤公雄, 大塚研一, 相馬扸和: 鉄と鋼, 68 (1982), p. 750

23）長城徹也, 井门泰孝, 萬谷志郎: 鉄と鋼, 71 (1985), p. 204

24) K. Koch, U. Härter and R. Bruckhaus: Steel Research, 60 (1989), p. 171

25) Y. Sasaki, S. Hara, D. R. Gaskell and G. R. Belton: Metall. Trans. B, 15B, (1984), p. 563

26) W. O. Philbrook and L. D. Kirkbride: J. Met., 8 (1956), p. 351

27) V. V. Kondakov and D. I. Ryzenkov: Izv. VUZ. Chern. Met. (1963) 1, p. 17

28) G. S. Ershov and Y. A. Popova: Izv. Akad. Nauk. SSSR Met. Gorn. Delo (1964) 1, p. 32

29) S. V. Shavrin and I. I. Zakharov: Izv. VUZ. Chern. Met. (1964) 5, p. 7 ; Izv. Akad. Nauk. SSSR Met. Gorn. Delo (1964) 2, p. 31
30) H. Krainer, H. P. Beer and H. Brandl: Techn. Mitt. Krupp. Forsch.-Ber., 24 (1966), p. 139

31 ) S. K. Tarby and W. O. Philbrook: Trans. Metall. Soc. AIME, 239 (1967), p. 1005

32) F. Fun: Metall. Trans., 1 (1970), p. 2537

33）須賀田正泰, 杉山 喬, 近藤真一: 鉄と鋼, 58 (1972), p. 1363

34) M. W. Daveis, P. N. Smith and G. S. F. Hazeldean Physical Chemistry of Process Metallurgy, The Richardson Conference, ed. by H. E. Jeffes, BSC, Sheffield, U. K. (1973), p. 95

35) C. Borgianni: Ironmaking Steelmaking, 5 (1978), p. 61

36）佐々木康, 岡本恭典, 相馬胤和: 鉄と鋼, 64 (1978), p. 367

37）佐藤 彰, 荒金吾郎, 広瀬文雄, 中川龍一, 吉松史朗: 鉄と鋼, 69 (1983), p. 384

38）原 茂太, 荻野和已: 鉄と鋼, 76 (1990), p. 360

39) J. F. Elliott: Trans. Metall. Soc. AIME, 227 (1955), p. 485

40）溶鉄·溶滓の物性値便覧（日本鉄鋼協会編）（1972）, p. 22

41) I. D. Sommerville, P. Grieveson and J. Taylor: Ironmaking Steelmaking, 7 (1980), p. 25

42) K. Upadhya, I. D. Sommerville and P. Grieveson: Ironmaking Steelmaking, 7 (1980), p. 33

43) M. Hacioglu and R. J. Pomfret: Proc. Intern. Symp. on Physical Chemistry of Iron and Steel Making, Toronto (1982), p. I. 27 [CIM]

44）片山英司, 田口整司, 桘谷暢男: 鉄と鋼, 68 (1982), p. 2279

45）林 昭二, 井口義章: 鉄と鋼, 77 (1991), p. 636

46) H. A. Fine, D. Meyer, D. Janke and H-J. Engell: Ironmaking Steelmaking, 12 (1985), p. 157

47) T. Nagasaka, Y. Iguchi and S. Ban-ya: Process Tech. Proc., ISS-AIME, 6 (1986), p. 169

48）長坂徹也, 井口泰孝, 萬谷志郎: 鉄と鋼, 75 (1989), p. 74

49) W. M. Kim, G. Gränzdörffer and H. A. Fine: Steel Research, 60 (1989), p. 166

50) M. Sasabe and M. Uehara: Trans. Iron Steel Inst. Jpn., 24 (1984), p. 34

51) P. C. Glaws and G. R. Belton: Metall. Trans. B, 21 (1990), p. 511

52) S. K. El-Rahaiby, Y. Sasaki, D. R. Gaskell and G. R. Belton: Metall. Trans. B, 17B (1986), p. 307

53) S. Sun, Y. Sasaki and G. R. Belton: Metall. Trans. B, 19B (1988), p. 959

54 ) S. V. Shavrin, I. I. Zakharov and G. S. Kulikov: Izv. Akad. Nauk. SSSR Met. Gorn. Delo (1964) 1, p. 26

55) Y. Sasaki and T. Soma: Metall. Trans. B, 8B (1977), p. 189

56）柴田 清, 北村寿宏, 徳光直樹: 鉄と鋼, 76 (1990), p. 2011

57) D. R. Sain and G. R. Belton: Metall. Trans. B, 7B (1976), p. 235

58) K. Ito and R. J. Fruehan: Metall. Trans. B, 20B (1989), p. 509,515

59) Y. Ogawa and N. Tokumitsu: Proc. 6th Iron Steel Congress, Nagoya, Vol. 1 (1990), p. 147 [ISIJ]

60）原 茂太, 荻野和巳: 鉄と鋼, 78 (1992), p. 200

61) H. A. Fine, R. J. Fruehan, D. Janke and R. Steffen: Steel Research, 60 (1989), p. 188 